Article

\title{
Ti-Nb Mineralization of Late Carbonatites and Role of Fluids in Its Formation: Petyayan-Vara Rare-Earth Carbonatites (Vuoriyarvi Massif, Russia)
}

\author{
Evgeniy Kozlov ${ }^{1, *(1)}$, Ekaterina Fomina ${ }^{1}$, Mikhail Sidorov ${ }^{1}$ and Vladimir Shilovskikh ${ }^{2}$ (D) \\ 1 Geological Institute, Kola Science Centre, Russian Academy of Sciences, 14, Fersmana Street, \\ 184209 Apatity, Russia; fomina_e.n@mail.ru (E.F.); sidorov@geoksc.apatity.ru (M.S.) \\ 2 Resource center for Geo-Environmental Research and Modeling (GEOMODEL), St. \\ Petersburg State University, 1, Ulyanovskaya Street, 198504 Saint Petersburg, Russia; vova_bel@mail.ru \\ * Correspondence: kozlov_e.n@mail.ru; Tel.: +7-953-758-7632
}

Received: 6 July 2018; Accepted: 25 July 2018; Published: 28 July 2018

\begin{abstract}
This article is devoted to the geology of titanium-rich varieties of the Petyayan-Vara rare-earth dolomitic carbonatites in Vuoriyarvi, Northwest Russia. Analogues of these varieties are present in many carbonatite complexes. The aim of this study was to investigate the behavior of high field strength elements during the late stages of carbonatite formation. We conducted a multilateral study of titanium- and niobium-bearing minerals, including a petrographic study, Raman spectroscopy, microprobe determination of chemical composition, and electron backscatter diffraction. Three $\mathrm{TiO}_{2}$-polymorphs (anatase, brookite and rutile) and three pyrochlore group members (hydroxycalcio-, fluorcalcio-, and kenoplumbopyrochlore) were found to coexist in the studied rocks. The formation of these minerals occurred in several stages. First, Nb-poor Ti-oxides were formed in the fluid-permeable zones. The overprinting of this assemblage by residual fluids led to the generation of $\mathrm{Nb}$-rich brookite (the main niobium concentrator in the Petyayan-Vara) and minerals of the pyrochlore group. This process also caused niobium enrichment with of early generations of Ti oxides. Our results indicate abrupt changes in the physicochemical parameters at the late hydro (carbo) thermal stage of the carbonatite formation and high migration capacity of $\mathrm{Ti}$ and $\mathrm{Nb}$ under these conditions. The metasomatism was accompanied by the separation of these elements.
\end{abstract}

Keywords: metasomatism; brookite; anatase; pyrochlore; niobium; carbonatites; Vuoriyarvi massif

\section{Introduction}

Carbonatites are defined in the International Union of Geological Sciences (IUGS) system of classification as igneous rocks containing more than 50 modal percent carbonate [1]. Varieties of carbonatite are named based on the dominant carbonate mineral [2]. They have been chemically classified according to the percent by mass of $\mathrm{CaO}, \mathrm{MgO}$, and $\mathrm{FeO}_{\mathrm{T}}$ and $\mathrm{MnO}$ [1], which has an evolutionary aspect as well. Most of the known carbonatite complexes have a common scheme of carbonatite genesis, whereby early calciocarbonatites were replaced by magnesiocarbonatites, and ferrocarbonatites, as the most recent [3]. The latter are considerably affected by carbo(hydro)thermal-metasomatic processes as they develop [4]. In general, carbonatites account for more than $50 \%$ of global rare-earth elements (REE) resources, which include $\mathrm{Y}$ and La-Lu [5]. REE enrichment is "most commonly found only in the latest and most highly evolved parts of a carbonatite intrusion" [6]. The accumulation of REE in late carbonatites is assumed to be controlled by fluid activity [7-16]. Such a surplus in articles reflects a keen interest in REE occurring in late carbonatites. More than $99 \%$ of the world's niobium $(\mathrm{Nb})$ is also 
known to be associated with carbonatite complexes [17]. Still, only a limited number of works were dedicated to the behavior of high field strength elements (HFSE), which include $\mathrm{Ti}, \mathrm{Nb}, \mathrm{Ta}, \mathrm{Zr}$, and $\mathrm{Hf}$, regardless of commercial value, at the final stages of the carbonatite genesis. The reason is that HFSE, unlike REE, are thought to be confined to the magmatic stage of the carbonatite genesis [18]. Moreover, a regular decrease in HFSE content occurs from early to late carbonatites [19]. However, this may not exclusively be the case.

In most carbonatite deposits, the main niobium concentrators are minerals of the pyrochlore group and, less frequently, the perovskite, columbite, and euxenite groups [17]. The deposits are divided into primary (i.e., primarily magmatic) and secondary. The latter are richer and are supposed to have accumulated $\mathrm{Nb}$ minerals and other HFSE, due to their low mobility in the areas of laterite weathering above primary deposits. As such, late carbonatites have a specific HFSE-mineralization. Examples include the industrially valuable deposits of the Magnet Cove complex in the U.S. [20,21], carbonatites of the Salpeterkop complex in South Africa [22], and the Gross Brukkaros complex in Namibia [23]. Nb-rich polymorphs of $\mathrm{TiO}_{2}$ play a key role in all the listed deposits. These minerals (anatase, rutile, and brookite) are also found in many other complexes [24]. They are typomorphic for late carbonatites and reflect the process that completes the picture of late carbonatite petrogenesis.

The evolution of the Morro dos Seis Lagos Nb (Ti, REE) deposit (Amazonas, Brazil) deserves particular attention. Here again, the main ore mineral is $\mathrm{Nb}$-rich rutile. Reserves of this deposit are tremendous: they are up to 2.9 billion tons with $2.81 \mathrm{wt} \% \mathrm{Nb}_{2} \mathrm{O}_{5}$ [25], which is much higher than in the largest known pyrochlore deposit. Hypergenesis certainly played a crucial role in the HFSE concentration process in the Morro dos Seis Lagos. However, laterites in this complex formed after ferro-(siderite)carbonatites that were originally rich in $\mathrm{Ti}$ and $\mathrm{Nb}$ [25]. In the Seis Lagos, like in many other complexes, $\mathrm{Nb}$-bearing oxides are described as secondary phases replacing originally magmatic pyrochlores, perovskites, and other minerals. Still, this mechanism is not universal for carbonatites. Pseudomorphing of originally magmatic minerals is commonly associated with direct deposition of $\mathrm{TiO}_{2}$ polymorphs from fluids. In the latter case, more $\mathrm{Nb}$ often occurs in titanium phases, as described for the Gross Brukkaros [23]. Moreover, some examples have no pseudomorphs of rutile, brookite, or anatase after other phases. Only paramorphs of certain $\mathrm{TiO}_{2}$ modifications have been found, like in the Magnet Cove [26]. This calls into question the existing models of HFSE mineralization in carbonatites.

Considering these challenges, decoding the processes of the late carbonatites petrogenesis is a major task. Determining these processes has both practical and fundamental value. The key step in the petrogenetic decoding is applying genetic mineralogy methods to $\mathrm{Ti}$ and $\mathrm{Nb}$ oxides [23,27-29]. The real challenge is dividing the late metasomatic changes and hypergenesis processes, which obscure earlier processes. The task becomes easier in the Vuoriyarvi. Weathering crusts that existed before the latest glaciations were eroded by glacial abrasion. Subsequently, almost no hypergenesis processes occurred due to the site's location in the sub-Arctic region [30]. These "preserved" sites help to identify products of late hydrothermal alteration and those of hypergenetic processes [31]. Studying the evolution of the Ti-Nb mineralization in the Petyayan-Vara has supported a high migration capacity at the late hydrothermal stage of such immobile elements as $\mathrm{Ti}$ and $\mathrm{Nb}$. We have also found evidence of fluid activity being accompanied by these elements' fractionation.

\section{Geological Setting of the Petyayan-Vara Rocks}

This research focused on the poorly studied carbonatites of the Petyayan-Vara area at the eastern flank of the Vuoriyarvi alkaline-ultrabasic carbonatite complex, southwest of the Murmansk region, Northwest Russia. The Vuoriyarvi is one of the Devonian Kola Alkaline Province massifs [32]. Its concentrically zonal structure (Figure 1) includes almost all rock varieties typical for such massifs [33]. 


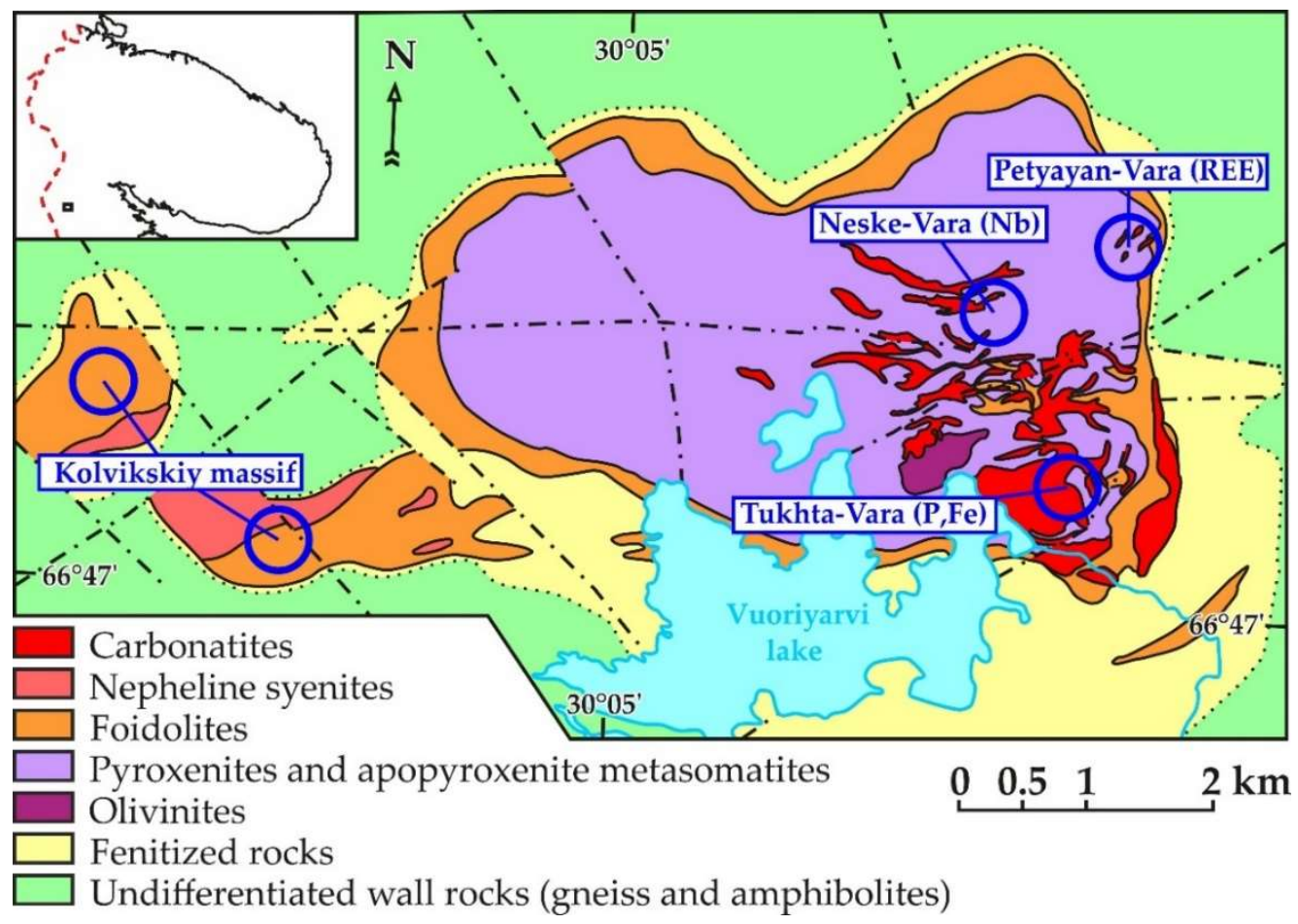

Figure 1. The geological setting and structure of the Vuoriyarvi alkaline-ultrabasic carbonatite complex after [33], simplified and added. Blue circles indicate positions of the Tukhta-Vara, Neske-Vara and Petyayan-Vara carbonatite fields and the Kolvikskiy agpaitic nepheline-syenite massif-satellite.

Thus, at the current erosion section, the massif core is composed of olivitites (the first phase of intrusion) surrounded by pyroxenites (the intermediate ring, second phase) and foidolites (the outer ring, third phase). The next (fourth) stage of the magma intrusion produced nepheline syenites and related rocks concentrated in the Kolvikskiy massif-satellite mostly. The youngest formations of the Vuoriyarvi are stockwork-like bodies of various carbonatites (fifth phase) cutting other rocks and forming several separated fields. Thus, near the Tukhta- and Neske-Vara tops, mostly calcite and, to a lesser extent, dolomite carbonatites and phoscorites are found. The Tukhta-Vara carbonatites include a deposit of apatite-magnetite-forsterite and rare metal (baddeleyite) ores. This deposit is close to the well-known Kovdor deposit (Kola Peninsula, Russia). On the Neske-Vara upland, along with apatite-magnetite ores, a deposit of niobium and tantalum exists, including more than 110 tons of $\mathrm{Ta}_{2} \mathrm{O}_{5}$ reserves and 4750 tons of $\mathrm{Nb}_{2} \mathrm{O}_{5}$. Their major concentrators are pyrochlore, hatchettolite, and zirkelite [33]. Thus, the Vuoriyarvi massif is a typical alkaline-ultrabasic carbonatite formation both structurally and compositionally.

Most carbonatite fields contain minor amounts of late varieties. The exceptions are the Petyayan-Vara carbonatites that include pyroxenite-cutting veins and lenses. They are as long as several hundred meters and tens of meters thick. The Petyayan-Vara carbonatites are spatially associated with phlogopite glimmerites metasomatically formed after pyroxenites. The orientation and morphology of the above carbonatite bodies are close to those of calcite carbonatites (soevites) from the Petyayan-Vara surroundings. However, the carbonatite bodies differ from these rocks with their wide range of mineralogical parageneses and a scope of mineralization, making them unique both for the Vuoriyarvi massif and for the Kola Alkaline Province in general. Magnesiocarbonatites are widespread within the Petyayan-Vara field (Figure 2), but unaltered primary magmatic dolomite carbonatites are rare. 


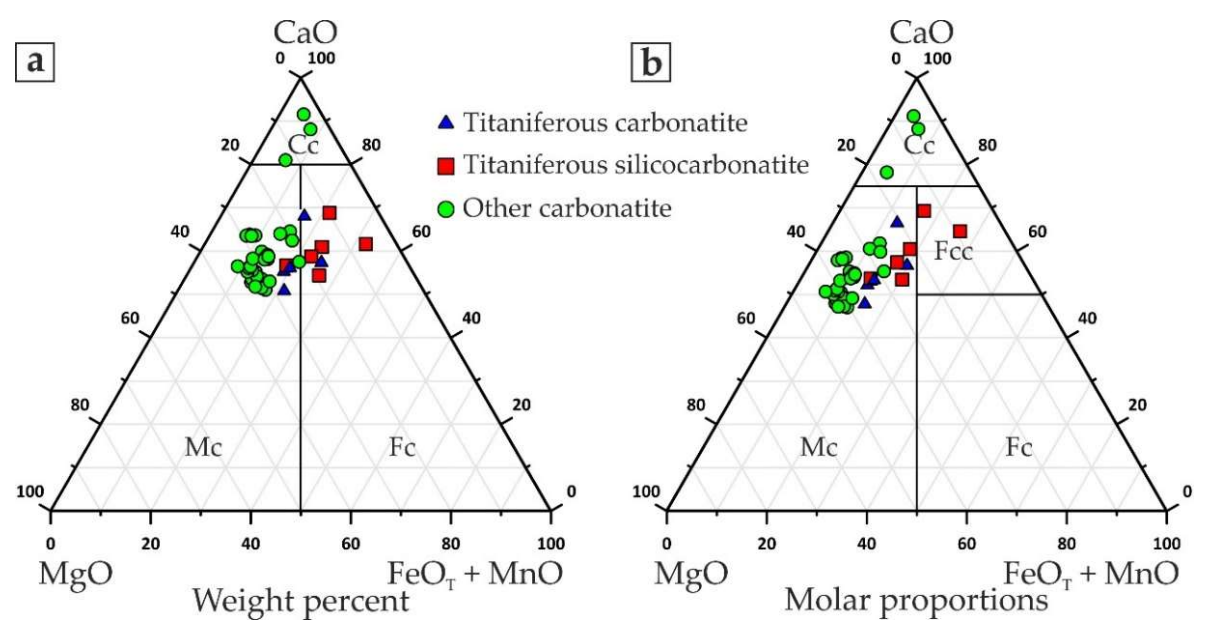

Figure 2. Composition points of the "titaniferous" carbonatites (blue triangles) and silicocarbonatites (red squares), as well as all other carbonate rocks of the Petyayan-Vara area (green circles) on the classification diagrams from (a) Woolley and Kempe [2] and (b) Gittins and Harmer [34]. Symbols: Cc—calcicocarbonatites, Mc—magnesiocarbonatites, Fc-ferrocarbonatites, and Fcc-ferruginous calciocarbonatites.

Specific varieties of carbonatites are more common in the investigated carbonatite bodies. These are:

(1) Fine-grained dolomitic carbonatites and silicocarbonatites with microcline and/or phlogopite (hereinafter called titaniferous carbonatites), locally enriched with apatite (carbonatites with K-Al-Si-Ti-Fe \pm P specialization);

(2) Medium-grained dolomitic carbonatites with barite, strontianite, and ancylite-(Ce) $(\mathrm{Ce}, \mathrm{La}) \mathrm{Sr}\left(\mathrm{CO}_{3}\right)_{2}(\mathrm{OH}) \times \mathrm{H}_{2} \mathrm{O} \pm$ bastnaesite-(Ce) $(\mathrm{Ce}, \mathrm{La})\left(\mathrm{CO}_{3}\right) \mathrm{F}$ (carbonatites with Ba-REE-Sr specialization); and

(3) Breccias of dolomitic carbonatites with cement consisting of fine-grained quartz and hydroxylbastnaesite-(Ce) $(\mathrm{Ce}, \mathrm{La})\left(\mathrm{CO}_{3}\right)(\mathrm{OH})$ (carbonatites with REE-Si specialization).

In the structure of carbonatite bodies, these varieties are closely intertwined with each other, as well as with primary dolomitic carbonatites and glimmerites. The most widespread are medium-grained dolomitic carbonatites with baryte, strontianite, and ancylite-(Ce). All these minerals either corrode the primary magmatic dolomitic carbonatites or form cement in their breccias. In the latter case, the texture of the rocks is similar to that of breccias of dolomitic carbonatites with fine-grained quartz-hydroxylbastnaesitic-(Ce) cement. Thus, most of the Petyayan-Vara carbonatites are typical Ba-Sr-REE-carbonatites with contents of $\mathrm{BaO}$ up to $17 \mathrm{wt} \%$, $\mathrm{SrO}$ up to $9 \mathrm{wt} \%$, and $\mathrm{REE}_{2} \mathrm{O}_{3}$ up to $14 \mathrm{wt} \%$. Just like their protolith (magnesiocarbonatites), they are almost completely depleted in HFSE.

Titaniferous carbonatites are also common and spatially close to the marginal parts of veins. They stand out both macroscopically owing to their specific reddish-brown color and dense fine-grained structure (Figure 3a) and by their mineralogical-geochemical characteristics. It is not clear at present whether magnesiocarbonatites were their protolith or if they formed (auto)metasomatically after carbonatites of an additional intrusion phase, or after host aluminosilicate rocks. The key role of metasomatism in the evolution of titaniferous carbonatites is undoubted, as indicated by a widely distributed streaky mineralization, corrosion structures, amoeboid xenomorphic forms, and their loose spongy texture (Figure $3 b$ ). This is also confirmed by the pseudomorphic substitution of some minerals by others, e.g., phlogopite by potassium feldspar (Figure 3c). Metasomatic recrystallization that made the rocks fine-grained and, as a result, poorly permeable by fluids. Later associations, 
including Ba-Sr-REE, occur in titaniferous carbonatites only along cracks in veinlets and in the cement of brecciated areas.
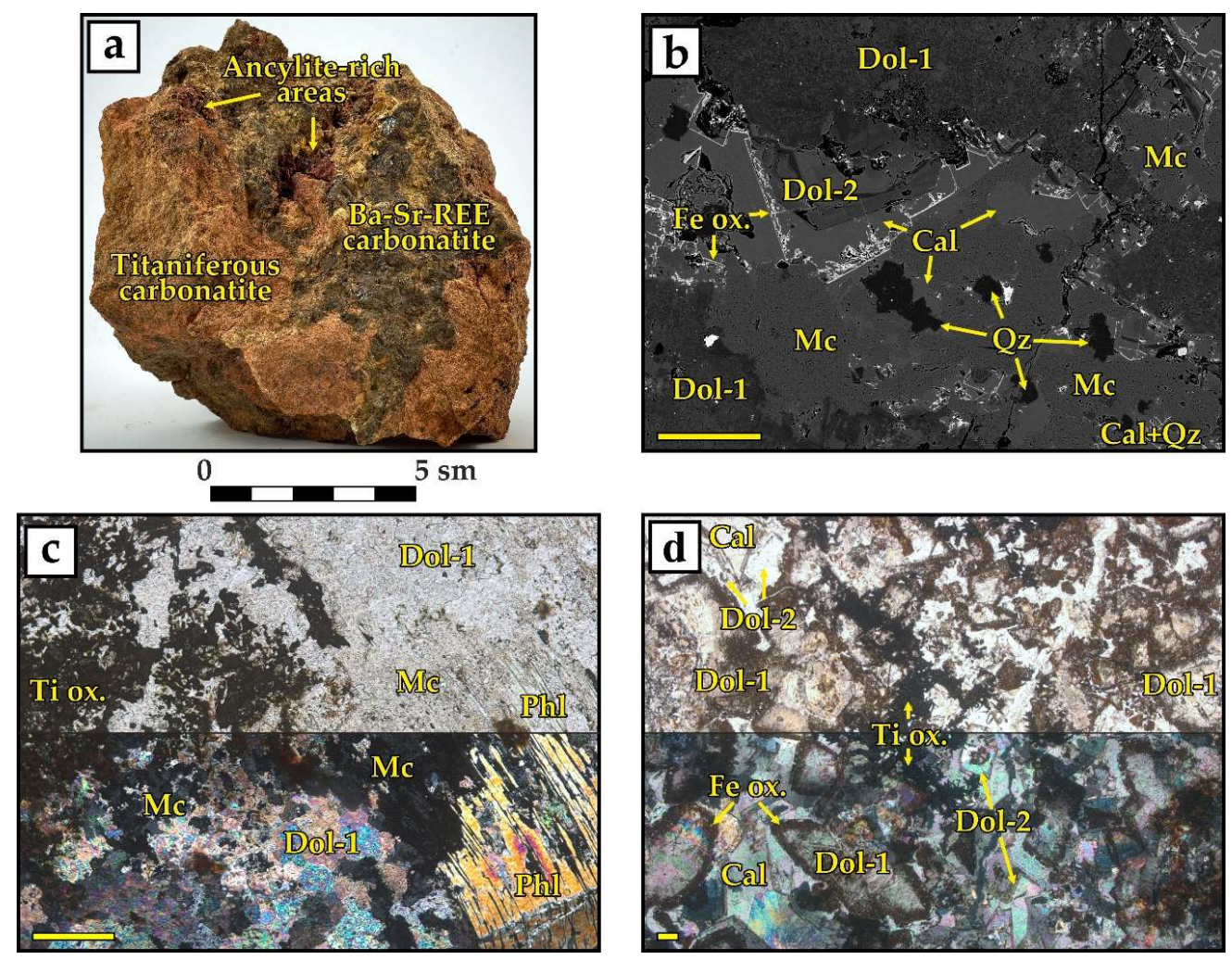

Figure 3. (a) The relationship of Ba-Sr-rare earth elements (REE) (dark brown) carbonatites and titaniferous (reddish-brown) carbonatites, as well as ancylite-rich (red) areas; (b) groundmass texture of the typical titaniferous carbonatite, amoeboid xenomorphic forms of minerals, and their loose spongy texture; (c) substitution of microcline by phlogopite; and (d) $\mathrm{TiO}_{2}$-carbonate (dolomite + calcite) veinlets in the dolomite carbonatite. Image (b) in backscattered electrons (BSE), (c,d) are in transmitted light [top-in plane-polarized light, bottom—in cross-polarized light]; Cal: calcite, Dol: dolomite (the numbers correspond to the generations, see explanation in the text), Mc: microcline, Qz: quartz, Phl: phlogopite, Ti ox.: titanium oxides (anatase, brookite and/or rutile), and Fe ox.: oxides-hydroxides of Fe. Scale rulers are $200 \mu \mathrm{m}$ in length.

Titanium oxides are rock-forming minerals of titaniferous carbonatites. Geochemically, their presence reflects highly $\mathrm{TiO}_{2}$-enriched rocks (0.9-4.4 wt \% with median [Me] of $2.3 \mathrm{wt} \%$ for 11 samples). Titanium varieties are also rich in $\mathrm{SiO}_{2}$ (8.1-35.1 [Me 21.8] wt \%), $\mathrm{Al}_{2} \mathrm{O}_{3}$ (2.6-7.7 [Me 3.9] wt \%), and $\mathrm{K}_{2} \mathrm{O}(2.0-5.9$ [Me 3.5] wt \%), which is not typical of carbonatites. At the mineralogical level, these geochemical characteristics are reflected by, along with ferruginous dolomite and calcite, a sodium-free microcline, phlogopite and, in minor amounts, albite, titanium aegirine, and quartz. Interestingly, sulfides (mainly pyrite) are only widespread in titaniferous carbonatites only, whereas in later metasomatites, almost all sulphur is sulphate and occurs in barite. According to the current IUGS classification [1], varieties with more than $20 \mathrm{wt} \% \mathrm{SiO}_{2}$ are silicocarbonatites. In the studied area, silicocarbonatites only occur among titaniferous rocks, with microline containing the greatest amount of silica. Among titaniferous rocks, some samples are highly rich in Th-Y-apatite $\left(\mathrm{P}_{2} \mathrm{O}_{5}\right.$ up to $7.5 \mathrm{wt} \%)$, though the phosphorous content in most of these rocks is not that high (Me $0.5 \mathrm{wt} \%)$. The contents vary since the apatitization is imposed on the Ti-alkaline alumosilicate association. Compared to the Petyayan-Vara Ba-Sr-REE-carbonatites, Ti-rich varieties have low concentrations of $\mathrm{BaO}\left(0.1-2.8\right.$ [Me 0.2] wt \%), SrO (up to 0.9 [Me 0.1] wt \%), and $\mathrm{REE}_{2} \mathrm{O}_{3}(0.2-1.4[\mathrm{Me} 0.3]$ wt \%). 
The concentrations are close to those in dolomite carbonatites. The Petyayan-Vara titaniferous carbonatites show the highest concentrations of iron, localized in the ankerite component of dolomite and in Fe oxides-hydroxides, providing the rocks with their specific coloring. As a result, in $\mathrm{CMF}$ classification charts $\left(\mathrm{CaO}-\mathrm{MgO}-\mathrm{FeO}_{\mathrm{T}}+\mathrm{MnO}\right)$ [2,34], figurative points of titaniferous carbonatites shift toward the field of ferrocarbonatites (Figure 2).

At a distance of a few meters from titaniferous varieties, "ordinary" dolomite carbonatites there have fine $\mathrm{TiO}_{2}$-carbonate (dolomite and calcite) veinlets that formed along joints (Figure 3d). The only feature that differentiates dolomite carbonatites with such veinlets from unaltered dolomite carbonatites is an increased $\mathrm{TiO}_{2}$ content (up to $1.1 \mathrm{wt} \%$ ). The veinlets per se indicate the mobility of titanium in late stage fluids. In isolated instances, in dolomite carbonatites from the rimming of titaniferous varieties, jointing controls the pyrochlore mineralization without $\mathrm{TiO}_{2}$-associated enrichment. In this case, the concentration of $\mathrm{Nb}$ increased up to $1500 \mathrm{ppm}$ with the average content of 400-800 ppm in titaniferous varieties and 10-100 ppm in other carbonatites of the Petyayan-Vara.

\section{Research Material and Analytical Methods}

Eleven samples of K-feldspar- and/or phlogopite-bearing titaniferous carbonatites and silicocarbonatites were sampled from three carbonatite bodies of the Petyayan-Vara as a study material. Several samples of dolomite carbonatites from the rimming of titaniferous varieties were studied that contained the titanium and niobium veinlet mineralization.

Titanium oxides (anatase, brookite, and rutile) are barely discernible both optically and in terms of their chemical composition. Therefore, we have studied them using methods based on structural characteristics of minerals: Raman spectroscopy (RS) and electron back scattered diffraction (EBSD). The former method is efficient due to differences in the Raman spectra of $\mathrm{TiO}_{2}$ polymorphs [35]. The Raman spectra were recorded on a HORIBA Jobin-Yvon LabRam HR800 laser Raman spectrophotometer (Horiba, Kyoto, Japan) on the Olympus confocal microscope (100× lens) in the range of $50-4000 \mathrm{~cm}^{-1}$ with a spectral resolution of $2 \mathrm{~cm}^{-1}$. The Raman scattering signal was excited by a green laser $(514.5 \mathrm{~nm})$ with the power of $50 \mathrm{~mW}$ (acquisition time 4-5 s, 10-15 acquisitions). The calibration was checked using a Raman line of silicon at $521 \mathrm{~cm}^{-1}$. Being highly productive, RS has been used for express identification of microprobe test points.

Using the electron backscatter diffraction (EBSD) allowed for the visualization of the $\mathrm{TiO}_{2}$ polymorphs ratios and defining boundaries of individual grains in intergrowths, where grains are constrained by mineral sections with a single crystallographic orientation in space. For EBSD measurements, a Hitachi S-3400N scanning electron microscope equipped with Oxford HKLNordlys EBSD detector was used. Operating conditions were as follows: accelerating voltage $20 \mathrm{kV}$, beam current $1 \mathrm{nA}$, acquisition time $16 \mathrm{~s}$, and step $2 \mu \mathrm{m}$ for one EBSD during mapping. Oxford Instruments AZtecHKL analysis software was used to identify the crystal orientation from the Kikuchi pattern, using the crystal structures of rutile, anatase and brookite from the Inorganic Crystal Structure Database. In order to obtain the flattest surface possible for an EBSD analysis, a sample was polished with an ending stage of Ar-ion etching for 10 min (Oxford IonFab 300).

The chemical heterogeneity of minerals was analyzed using BSE-images and maps of element distribution provided by scanning electron microscopes (SEM). The chemical composition of the minerals was detected using SEM Hitachi S-3400N with Oxford X-Max 20 energy dispersive X-ray spectrometer (EDS) (20 kV, $1 \mathrm{nA}, 30 \mathrm{~s}$ per exposure) and a wavelength-dispersive spectrometer (WDS) Cameca MS-46 electron microprobe ( $22 \mathrm{kV}, 30 \mathrm{nA}, 50 \mathrm{~s}$ per exposure). EDS data were gathered with no standards and WDS data were calibrated using natural and synthetic standards. Two phases and lines were selected to calibrate the data: wollastonite $(\mathrm{Si} K \alpha, \mathrm{Ca} K \alpha)$, anatase $(\mathrm{Ti} K \alpha)$, hematite $(\mathrm{Fe} K \alpha)$, apatite $(\mathrm{P} K \alpha)$, lorenzenite $(\mathrm{NaK} \alpha)$, wadeite $(\mathrm{K} K \alpha)$, zircon $(\mathrm{Zr} L \alpha)$, thorite $(\mathrm{Th} M \alpha)$, metallic $\mathrm{Nb}(\mathrm{Nb} L \alpha)$, metallic Ta $(\mathrm{Ta} L \alpha)$, metallic U $(\mathrm{UM} \alpha), \mathrm{SrSO}_{4}(\mathrm{Sr} L \alpha), \mathrm{BaSO}_{4}(\mathrm{Ba} L \alpha), \mathrm{PbMoO}_{4}(\mathrm{~Pb} L \alpha), \mathrm{Y}_{3} \mathrm{Al}_{5} \mathrm{O}_{12}(\mathrm{Y} L \alpha)$, $(\mathrm{La}, \mathrm{Ce}) \mathrm{S}(\mathrm{La} L \alpha), \mathrm{CeS}(\mathrm{Ce} L \alpha), \mathrm{LiNd}\left(\mathrm{MoO}_{4}\right)_{2}(\mathrm{Nd} L \alpha), \mathrm{SmFeO}_{3}(\mathrm{SmL} \alpha)$. The detection limit for Si, Ti, Ca, $\mathrm{Fe}, \mathrm{K}$, and $\mathrm{Cl}$ was $0.02 \% ; 0.05 \%$ for $\mathrm{P}, \mathrm{Na}, \mathrm{Sr}, \mathrm{Ba}, \mathrm{Ta}, \mathrm{Y}, \mathrm{La}, \mathrm{Ce}, \mathrm{Nd}, \mathrm{Pr}$, and $\mathrm{Sm}$; and $0.1 \%$ for $\mathrm{Zr}, \mathrm{Nb}, \mathrm{U}$, 
$\mathrm{Th}$, and $\mathrm{Pb}$. The data were reduced using the original matrix correction technique [36]. The fluorine content was detected using a LEO-1450 SEM equipped with an XFlash-5010 Bruker Nano GmbH EDS $(20 \mathrm{kV}, 0.5 \mathrm{nA}, 200 \mathrm{~s}$ per exposure). Data reduction was performed using standard-free analysis based on the P/B-ZAF method of the QUANTAX system. The comparison of the results obtained from WDS (with standards) and EDS (without standards) on pyrochlores and titanium oxides showed that normalized results were close for both minerals, though the EDS analyses indicated underweight.

The value of $\mathrm{Ti}+\mathrm{Nb}+\mathrm{Fe}_{\mathrm{T}}$ is given as 1.00 atom per formulae unit (a.p.f.u.), when crystallochemical formulas of titanium oxides are calculated [23]. $\mathrm{Fe}^{2+}$ and $\mathrm{Fe}^{3+}$ ratios were not evaluated for the reason provided in Section 4.1. Crystallochemical formulas of the pyrochlore group minerals share a common view: $A_{2-\mathrm{m}} B_{2} \mathrm{X}_{6-\mathrm{w}} \mathrm{Y}_{1-\mathrm{n}}$, where $A=\mathrm{Na}, \mathrm{Ca}, \mathrm{Sr}, \mathrm{Ba}, \mathrm{Fe}^{2+}, \mathrm{Pb}^{2+}, \mathrm{Sn}^{2+}, \mathrm{Sb}^{3+}, \mathrm{Y}, \mathrm{Ce}$ (and other REE), $\mathrm{U}$, $\mathrm{Th}, \square$ or $\mathrm{H}_{2} \mathrm{O} ; B=\mathrm{Ta}, \mathrm{Nb}, \mathrm{Ti}, \mathrm{Sb}^{5+}, \mathrm{W}, \mathrm{V}^{5+}, \mathrm{Sn}^{4+}, \mathrm{Zr}, \mathrm{Hf}, \mathrm{Fe}^{3+}$ and $\mathrm{Si} ; \mathrm{X}$ typically is $\mathrm{O}$, but can include subordinate $\mathrm{OH}$ and $\mathrm{F} ; \mathrm{Y}$ typically is $\mathrm{OH}^{-}, \mathrm{F}, \mathrm{O}, \square, \mathrm{H}_{2} \mathrm{O}$ [37]. The formulas were calculated based on the notion that the $B$-site has no vacancies; therefore, the $\mathrm{Nb}+\mathrm{Ta}+\mathrm{Ti}+\mathrm{Zr}+\mathrm{Si}+\mathrm{Fe}_{\mathrm{T}}$ sum is 2.00 a.p.f.u. $\mathrm{O}$ and $\mathrm{OH}$ were calculated considering the balance of charge and stoichiometry. Since $\mathrm{Fe}_{\mathrm{T}}$ content increased by 0.05 a.p.f.u. in only in a few probes, like in [28], we have also decided not to divide $\mathrm{Fe}^{2+}$ and $\mathrm{Fe}^{3+}$.

\section{Results}

\subsection{Titanium Minerals}

In titaniferous carbonatites, glomeroblast clusters of titanium oxides grains are tightly associated with xenomorphic individuals of K-feldspar and F-rich phlogopite laths, if the latter are present. Raman spectroscopy indicated Ti oxides occur as three polymorph modifications: anatase, rutile, and brookite. Brookite predominates in titaniferous carbonatites, anatase is minor, and rutile produces paramorphs after both minerals. Brookite is dark brown to yellowish brown in transmitted light, anatase is indigo, and rutile is brown or blood red. However, these minerals are commonly grouped in morphologically different muddy brown aggregates that hamper optic diagnostics. Five morphotypes of titanium oxide isolations were detected in titaniferous carbonatites: segregations of elongated crystals (I type), xenomorphic rims of carbonatite grains overgrowths (II type), amoeboid isolations (III type), specific "cementing" intergrowths with sulfides (IV type), and small idiomorphic individuals of brookite (V type) (Figure 4a-e, respectively). I-IV type isolations occur mostly in a rock tissue or less frequently within K-feldspatized carbonate veinlets. These transformed veinlets are often visible only due to their shady structure accentuated by relic areas of late dolomite adjacent to selvages. This dolomite differs from the muddy spongy one of the main rock tissue with its dense structure, idiomorphic appearance, and fine oscillation zoning. The V type idiomorphic brookite was solely observed in by-selvage areas of well-preserved cutting calcite veinlets associated with a late generation of dolomite. Note, I type segregations are also composed preliminary of brookite (Figure 4f), although elongated crystals are typical for anatase and rutile.

Amoeboid isolations of $\mathrm{TiO}_{2}$ (III type) are the most widespread. They provide a full view of the mineral genesis as they include three polymorphs in their structure. Anatase grains occur as fragments, with the biggest ones in the brookite mass and the smaller ones occurring outside as constellations (Figure 5a). Brookite constitutes more than $80 \mathrm{vol} \%$ of isolations, which corresponds with its share in the balance of $\mathrm{TiO}_{2}$ for titaniferous carbonatites. Brookite is found to have formed in at least two stages. Earlier generation brookite, Brk-1 is chemically homogenous (Figure 5b) upon which radial paramorphs of rutile developed. Rutile is likely to have a cell structure (Figure 5c) due to different densities of brookite (4.08-4.18 $\mathrm{g} \mathrm{sm}^{-3}$ ) and rutile (4.23-5.50 $\mathrm{g} \mathrm{sm}^{-3}$ ) [38] which as a result, decrease in its volume. Rutile differs from other titanium oxides with an increased content of admixtures: Ca, $\mathrm{Si}$, as well as $\mathrm{P}$ and $\mathrm{Na}$ (according to a number of analyses). We presumed it to result from calcite, aegirine, and apatite filling extra volume that occurred in the paramorph substitution. The above 
minerals compose the paragenetic association of the apatitization. The latter, as stated, is imposed on the rock-forming association of titaniferous carbonatites.
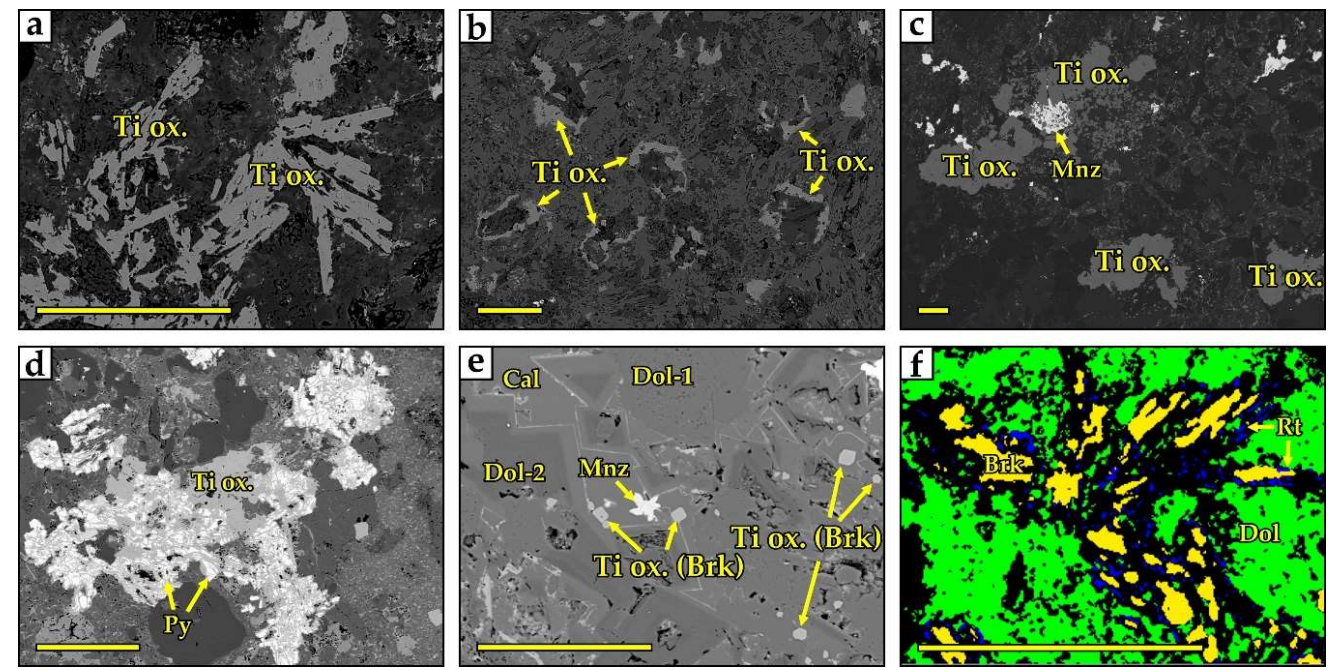

Figure 4. Morphotypes of titanium oxide isolations: (a) I type-segregations of elongated crystals, (b) II type-xenomorphic rims of carbonatite grains overgrowths, (c) III type-amoeboid isolations, "bright" mineral is monazite (Mnz), (d) IV type—specific "cementing" intergrowths with pyrite (Py), and (e) V type-small idiomorphic individuals of brookite. (f) Electron back scattered diffraction (EBSD) phases map of the I type of titanium oxide isolations, hereinafter on EBSD phases maps (Figure 5a,b and Figure 6b): green-dolomite (Dol), yellow—brookite (Brk), red-anatase (Ant), blue-rutile (Rt). Images (4a-e) are in backscattered electrons (BSE). Scale rulers are $200 \mu \mathrm{m}$ long.
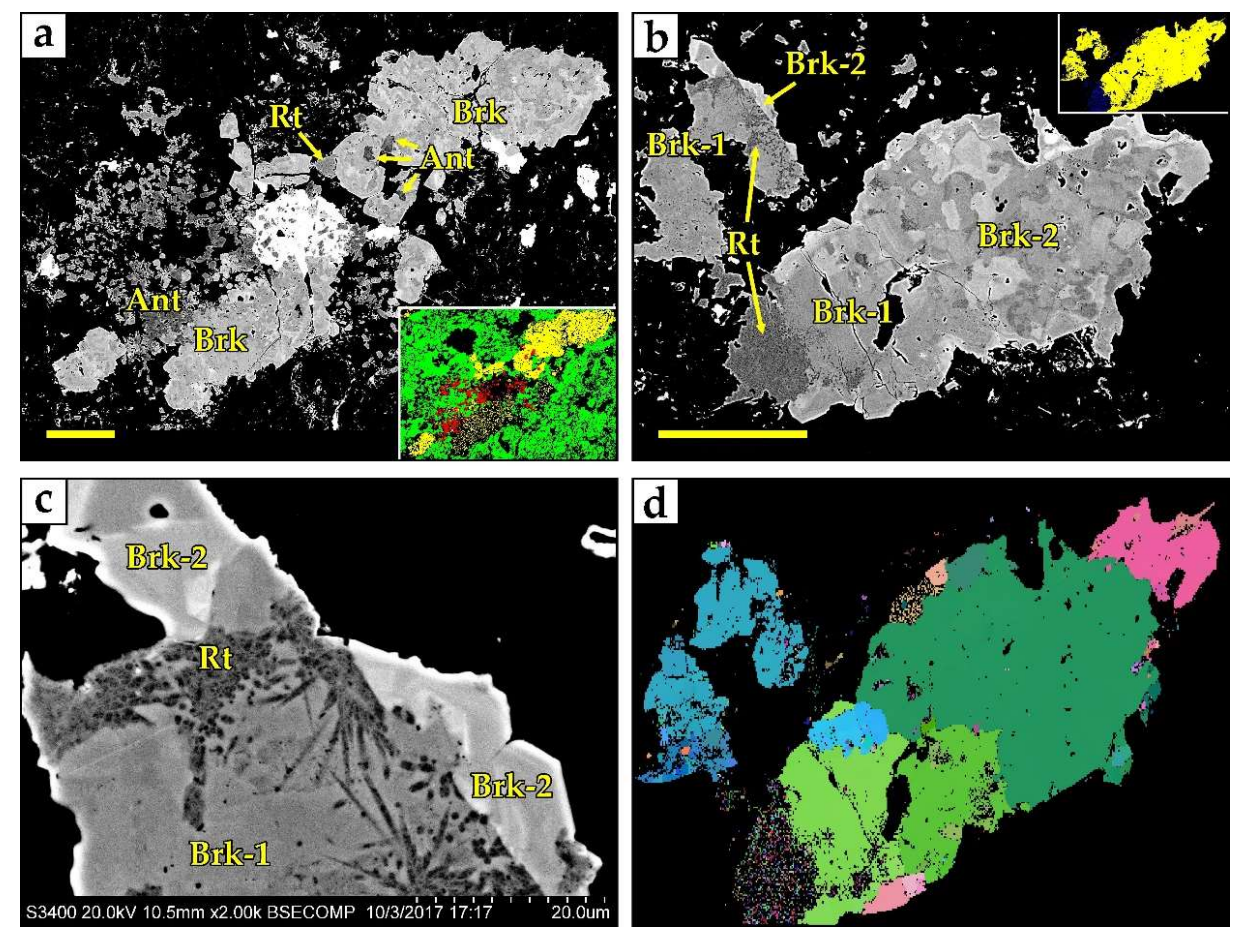

Figure 5. $(\mathbf{a}, \mathbf{b})$ Anatomy of amoeboid isolations of $\mathrm{TiO}_{2}$ (III type), contrasting BSE-images. On the inserts are phase distribution maps within the same sections, obtained by the EBSD; (c) substitution of brookite by rutile; and (d) Euler angle coloring orientation map for the (b) section, colors reflect the proximity of the orientation of crystals. Scale rulers are $200 \mu \mathrm{m}$ long. 
Later generation brookite, Brk-2 overgrowths both Brk-1, and the rutile developed on it. Its $\mathrm{Nb}$ content also varies, providing the mineral with a mosaic appearance in BSE-images. However, according to the EBSD results (Figure 5d), despite the block structure of amoeboid isolations, they are composed of individual monocrystals, where brookites of both generations are jointed.

The content of $\mathrm{Nb}_{2} \mathrm{O}_{5}$ varied from 0.7 to $5.2 \mathrm{wt} \%$ in the studied grains of titanium oxides. Given the maximum distribution, brookite is the main concentrator of niobium in the Petyayan-Vara carbonatites. The distribution of niobium in the studied sampling was bimodal with clear maximums of $2.2 \mathrm{wt} \%$ and $4.3 \mathrm{wt} \%$ (Figure 6a). As showed Werner and Cook [23], in rocks similar to the Petyayan-Vara carbonatites, titanium oxides included $\mathrm{Nb}$ and $\mathrm{Fe}$ under two related schemes of isomorphism: $2 \mathrm{Ti}^{4+} \rightleftarrows \mathrm{Nb}^{5+}+\mathrm{Fe}^{3+}$ and $3 \mathrm{Ti}^{4+} \rightleftarrows 2 \mathrm{Nb}^{5+}+\mathrm{Fe}^{2+}$. In chart at coordinates $\mathrm{Nb}$ a.p.f.u. - Fe a.p.f.u. (Figure $6 \mathrm{~b}$ ) the field indicating combined impacts of the above schemes is bounded by lines with 0.5 and 1.0 inclines. Less than one-third of figurative points were found in this field; the rest were divided into

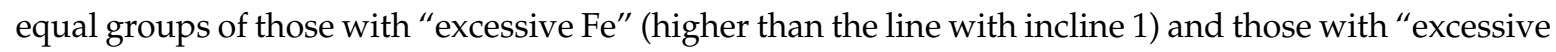
$\mathrm{Nb}^{\prime \prime}$ (lower than the line with incline 0.5). The appearance of excessive iron is a common feature that can be explained by mechanically included Fe oxides-hydroxides. Examples include brookite and rutile from the $\mathrm{Nb}$ (Ti, REE) deposit Morro dos Seis Lagos ([25]; see their Figure 12). The unusual pattern of the excessive $\mathrm{Nb}$ entry that is not compensated by Fe requires further research [39]. Thus, attempts at balancing $\mathrm{Fe}^{2+}$ and $\mathrm{Fe}^{3+}$ according to the scheme $\mathrm{Fe}^{2+} /\left(\mathrm{Fe}^{2+}+\mathrm{Fe}^{3+}\right) \approx 1-(\mathrm{Nb} / \mathrm{Fe})$ suggested by Werner and Cook [23] have failed and need further refinement.
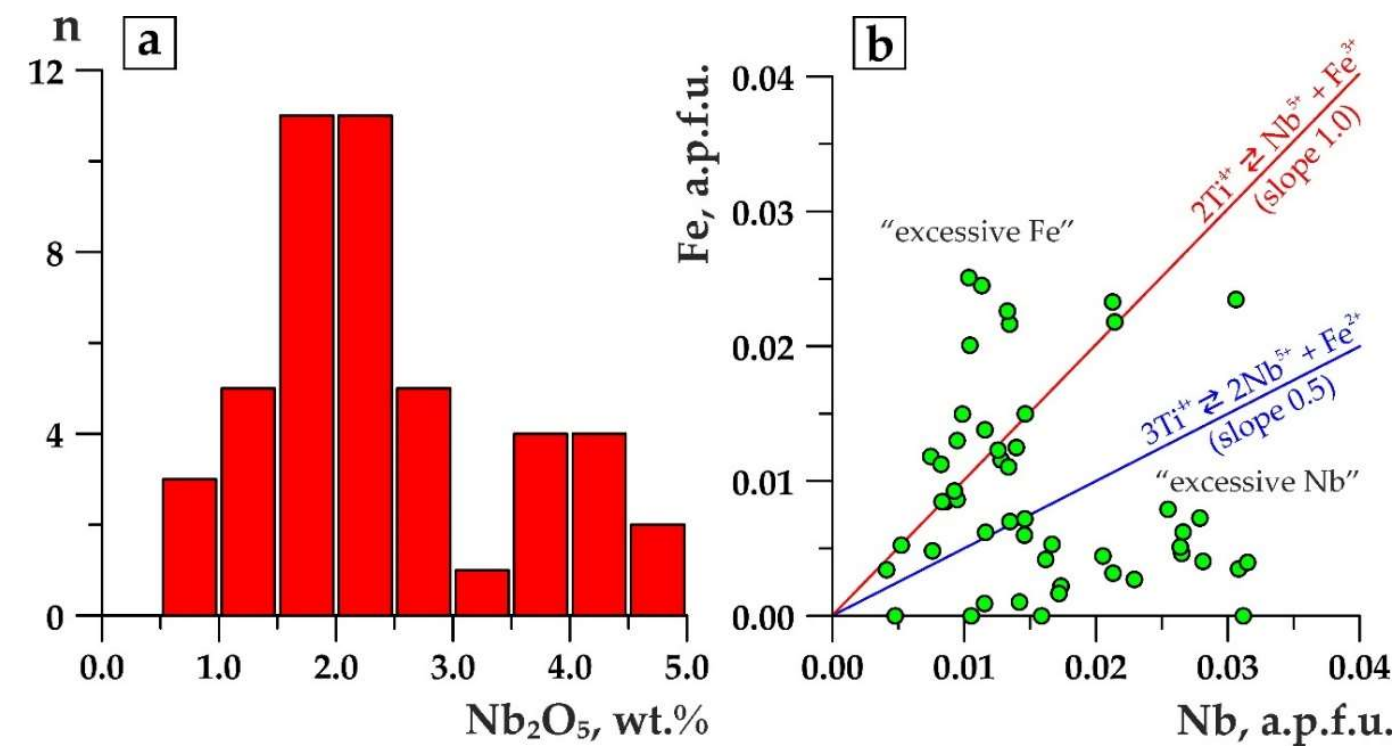

Figure 6. (a) Histogram of $\mathrm{Nb}_{2} \mathrm{O}_{5}$ distribution and (b) binary diagram $\mathrm{Ti}$ vs. $\mathrm{Nb}+\mathrm{Fe}^{3+}$ for the titanium oxides of the Petyayan-Vara titaniferous carbonatites.

Titaniferous carbonatites demonstrated a steady trend in the $\mathrm{Nb}$-enrichment of the later generation of brookite. In the surrounding primary dolomite carbonatites, the $\mathrm{TiO}_{2}$-dolomite-calcite veinlets contains titanium oxides with a different distribution of $\mathrm{Nb}$. Unlike titaniferous carbonatites, these phases were easily optically detected here (Figure 7a). In such veinlets, anatase and brookite occured in equal shares and are grouped in glomeroblast isolations, whereas rutile was scarce (Figure 7b). Morphologically, these glomers are close to the I type isolations of $\mathrm{TiO}_{2}$ from titaniferous carbonatites (cf. Figures $4 \mathrm{a}$ and $7 \mathrm{c}$ ). Anatase produces well-facetted fusiform crystals, whereas brookite either includes it with a poikilitic texture, or co-exists as idiomorphic isometric grains. BSE-images of the discussed glomers provided a clear picture of rims impregnating the edges of both anatase and brookite (Figure 7d). When untouched by these rims, anatase and brookite are low in niobium, and earlier anatase was poorer than brookite (on average, $0.2 \mathrm{wt} \%$ and $0.5 \mathrm{wt} \% \mathrm{Nb}_{2} \mathrm{O}_{5}$ respectively). 
In rimmings of both minerals, the $\mathrm{Nb}$ content dramatically increased up to $2.5 \mathrm{wt} \% \mathrm{Nb}_{2} \mathrm{O}_{5}$ in anatase and $5.0 \mathrm{wt} \%$ in brookite.
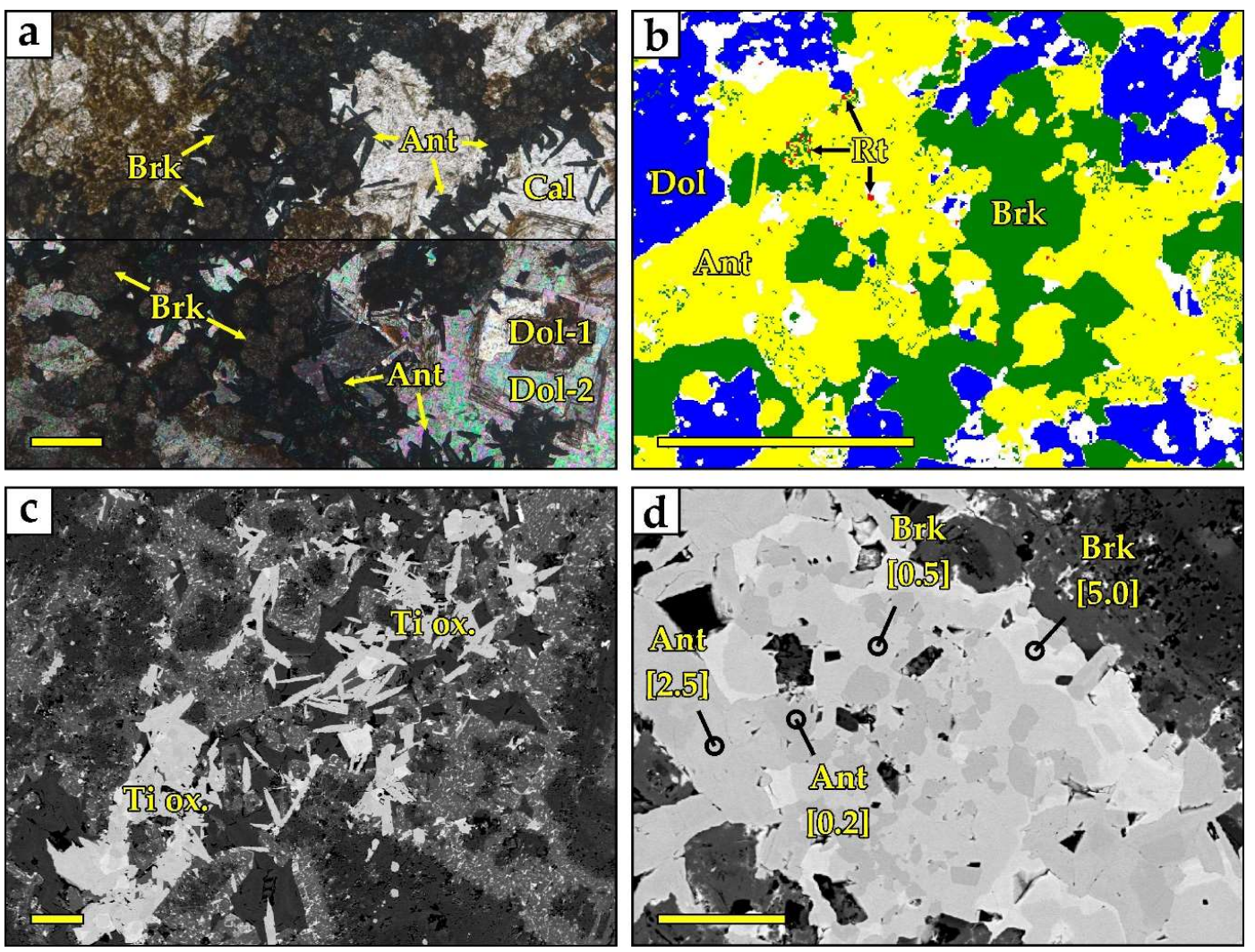

Figure 7. $\mathrm{TiO}_{2}$-carbonate veinlets in the dolomite carbonatite: (a) titanium oxides in transmitted light (top-in plane-polarized light, bottom-in cross-polarized light), (b) EBSD phases map, (c) morphology of titanium oxide isolations on the BSE image, and (d) an example of the distribution of $\mathrm{Nb}_{2} \mathrm{O}_{5}$ in the impregnating rims both in anatase and in brookite. In square brackets: contents of $\mathrm{Nb}_{2} \mathrm{O}_{5}(\mathrm{wt} \%)$. Scale rulers are $100 \mu \mathrm{m}$ long.

\subsection{Niobium Minerals}

Niobium minerals in the Petyayan-Vara carbonatites are represented solely by members of the pyrochlore group. In titaniferous varieties individual idiomorphic grains of well-preserved honey-yellow pyrochlore were detected in the by-selvedge areas of cutting calcite veinlets associated with a later generation of dolomite. Namely, pyrochlore maintains the same structural position, as V-type idiomorphic brookite, which is commonly associated with the latter. Most grains are zonal: (1) Th-variety with excessive Si and no F that compose the submicron embryos in a crystal core, (2) the main volume is occupied by Ca-F-pyrochlore substituted along rims and cracks, and (3) by Pb-pyrochlore without fluorine (Figure 8a,b). Both embryos and rims were not detected in every single crystal. Rims obviously tended toward the latest minerals, such as monazite. According to the IMA nomenclature, cores, intermediate areas, and rims of pyrochlore, the compositions of which are provided in Table 1 , refer to U-Th-rich hydroxycalciopyrochlore $(\mathrm{Ca}, \mathrm{Sr}, \mathrm{Th}, \mathrm{U}, \square)_{2}(\mathrm{Nb}, \mathrm{Ti})_{2} \mathrm{O}_{6}(\mathrm{OH})$, fluorcalciopyrochlore $(\mathrm{Ca}, \mathrm{Na})_{2}(\mathrm{Nb}, \mathrm{Ti})_{2} \mathrm{O}_{6}(\mathrm{~F}, \mathrm{OH})$, and kenoplumbopyrochlore $(\mathrm{Pb}, \square) \mathrm{Nb}_{2} \mathrm{O}_{6}(\square, \mathrm{O})$, respectively [37]. Studying $\mathrm{U}-\mathrm{Th}$ - and $\mathrm{Pb}$-varieties (in cores and rimes, respectively) with the WDS method has failed because of their small sizes. Their compositions were only evaluated with EDS, which was still rather accurate. First, the measurements did not include neighboring Ca-F-pyrochlore, as testified by the absence of $\mathrm{F}$ in both analyses and the absence of $\mathrm{Ca}$ in that of $\mathrm{Pb}$-pyrochlore. Second, the measured compositions were close to pyrochlores from other similar complexes, as will be highlighted in Section 5. We could 
not explain the excessive silica in the composition of the U-Th-rich variety. As shown by the study of the silicified pyrochlore from the Narssârssuk, Julianehaab district, Greenland, conducted by Bonazzi et al. [39], "50-70\% of the total silicon detected is incorporated in the radiation-damaged portions of pyrochlore". In our case, we consider thorium responsible for the radiation-damaged portions.
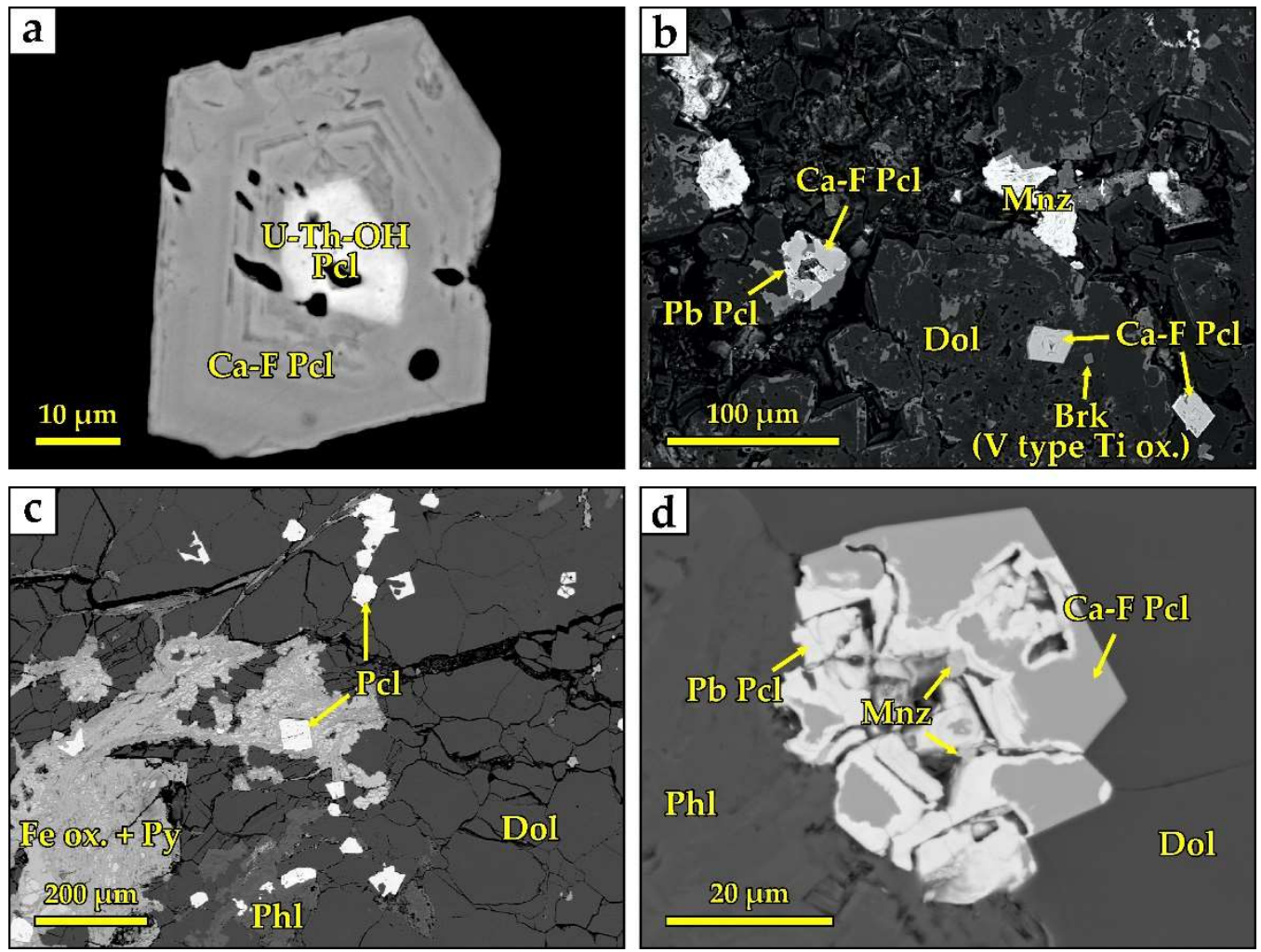

Figure 8. (a) U-Th-rich hydroxycalciopyrochlore (U-Th-OH Pcl) submicron embryos, surrounded by fluorcalciopyrochlore, (Ca-F Pcl); (b) euhedral crystals of fluorcalciopyrochlore in association with small idiomorphic individuals of brookite ( $\mathrm{V}$ type of $\left.\mathrm{TiO}_{2}\right)$, rims of kenoplumbopyrochlore $(\mathrm{Pb} \mathrm{Pcl})$ around fluorcalciopyrochlore; (c) chain-like pyrochlore mineralization associated with sulphides, Fe-oxides, and phlogopite in pyrochlore-rich areas near titaniferous varieties in dolomite carbonatites; and (d) resorption of euhedral pyrochlore on contact with phlogopite and substitution of fluorcalciopyrochlore (near the contact) by kenoplumbopyrochlore, associated with monazite.

As mentioned in Section 2, pyrochlore-rich areas were found near the titaniferous varieties in dolomite carbonatites. Here, pyrochlore was compositionally similar with fluorcalcio- and kenoplumbopyrochlore from titaniferous rocks (Table 1). Judging by the structural features, these areas dinamometamorphically changed before the pyrochlore mineralization. As a result, they formed a schistose fine-grained cataclastic structure enriched by magnetite. The pyrochlore mineralization was distributed in a chain-like manner and constrained by cracks cutting the schistosity (Figure 8c). Sulfides (pyrite) and Fe oxides-hydroxides developed along these cracks. Xenomorphic laths of phlogopite, which seemed to have occurred after pyrochlore, spatially tended toward small areas of the pyrochlore mineralization. At the contact with mica pyrochlore was clearly resorbed and always substituted by Pb-pyrochlore at edges. Pb-pyrochlore (Figure 8d) developed inwards along cracks and, in segregations of pyrochlore grains, crystal boundaries. In dolomite carbonatites with chain-like pyrochlore mineralization, no anatase, brookite, or rutile was observed. These rocks contained the Sr-Ba-REE mineralization represented by ancylite, barite, and bastnaesite. The minerals are late in terms of pyrochlore and phlogopite. Notably, late monazite often occurs in the studied dolomite carbonatites 
with the chain-like pyrochlore mineralization, as well as in titaniferous varieties, in association with $\mathrm{Pb}$-pyrochlore rims.

Table 1. Chemical compositions of representative pyrochlore crystals from the titaniferous carbonatites and the adjacent pyrochlore-rich areas in dolomite carbonatites of the Petyayan-Vara.

\begin{tabular}{|c|c|c|c|c|c|c|c|c|}
\hline Components & U-Th (1) ${ }^{1}$ & Ca-F (1) & Ca-F (2) & Ca-F (2) & $\mathrm{Pb}(1)$ & $\mathrm{Pb}(1)$ & $\mathrm{Pb}(2)$ & $\mathrm{Pb}(2)$ \\
\hline $\mathrm{BaO}$ & b.d.l. & b.d.l. & b.d.l. & b.d.l. & b.d.l. & b.d.l. & b.d.l. & b.d.l. \\
\hline $\mathrm{K}_{2} \mathrm{O}$ & b.d.l. & b.d.l. & 0.06 & 0.04 & b.d.l. & b.d.l. & b.d.l. & b.d.l. \\
\hline $\mathrm{Na}_{2} \mathrm{O}$ & b.d.l. & 4.66 & 6.84 & 6.73 & 0.36 & b.d.l. & b.d.l. & b.d.l. \\
\hline $\mathrm{SrO}$ & 4.09 & 1.41 & 1.19 & 1.25 & 1.42 & 1.80 & 2.00 & 3.13 \\
\hline $\mathrm{CaO}$ & 5.88 & 15.48 & 16.49 & 16.25 & 4.02 & 1.05 & 1.17 & 1.51 \\
\hline $\mathrm{PbO}$ & b.d.l. & b.d.l. & b.d.l. & b.d.l. & 32.14 & 31.10 & 26.81 & 25.41 \\
\hline $\mathrm{UO}_{2}$ & 3.18 & b.d.l. & b.d.l. & b.d.l. & b.d.l. & b.d.l. & b.d.l. & b.d.l. \\
\hline ThO & 9.71 & b.d.l. & b.d.l. & b.d.l. & b.d.l. & b.d.l. & b.d.l. & b.d.l. \\
\hline $\mathrm{Y}_{2} \mathrm{O}_{3}$ & b.d.l. & 0.72 & 0.43 & 0.42 & b.d.l. & b.d.l. & b.d.l. & b.d.l. \\
\hline $\mathrm{La}_{2} \mathrm{O}_{3}$ & 0.42 & b.d.l. & 0.40 & 0.51 & b.d.l. & 2.20 & 2.92 & 2.55 \\
\hline $\mathrm{Ce}_{2} \mathrm{O}_{3}$ & 2.47 & 0.66 & 0.74 & 0.93 & 0.54 & 4.21 & 5.75 & 5.29 \\
\hline $\mathrm{Nd}_{2} \mathrm{O}_{3}$ & 0.44 & b.d.l. & 0.19 & 0.20 & b.d.l. & 0.33 & 0.51 & 0.21 \\
\hline $\mathrm{Sm}_{2} \mathrm{O}_{3}$ & b.d.l. & b.d.l. & 0.20 & 0.22 & b.d.l. & b.d.l. & b.d.l. & b.d.l. \\
\hline $\mathrm{SiO}_{2}$ & 3.42 & b.d.l. & 0.12 & 0.26 & 0.47 & 0.16 & 0.26 & 0.60 \\
\hline $\mathrm{TiO}_{2}$ & 8.94 & 4.95 & 4.74 & 5.12 & 2.72 & 3.33 & 3.21 & 2.22 \\
\hline $\mathrm{Fe}_{2} \mathrm{O}_{3}$ & 3.24 & 0.39 & 0.11 & 0.17 & 0.71 & 0.57 & 0.73 & 0.61 \\
\hline $\mathrm{ZrO}_{2}$ & b.d.l. & b.d.l. & 0.30 & 0.48 & b.d.l. & b.d.l. & b.d.l. & b.d.l. \\
\hline $\mathrm{Nb}_{2} \mathrm{O}_{5}$ & 41.74 & 57.49 & 64.39 & 64.60 & 42.00 & 44.09 & 46.11 & 48.73 \\
\hline $\mathrm{Ta}_{2} \mathrm{O}_{5}$ & b.d.l. & b.d.l. & 0.17 & 0.10 & b.d.l. & b.d.l. & b.d.l. & b.d.l. \\
\hline $\mathrm{F}$ & b.d.l. & 3.80 & 2.84 & 2.85 & b.d.l. & b.d.l. & b.d.l. & b.d.l. \\
\hline Total & 83.53 & 89.56 & 99.21 & 100.13 & 84.38 & 88.84 & 89.47 & 90.26 \\
\hline $\mathrm{F}=\mathrm{O}$ & 0.00 & 1.60 & 1.20 & 1.20 & 0.00 & 0.00 & 0.00 & 0.00 \\
\hline Total & 83.53 & 87.96 & 98.01 & 98.93 & 84.38 & 88.84 & 89.47 & 90.26 \\
\hline \multicolumn{9}{|c|}{ Formula calculated to $2 B$-site cations } \\
\hline $\mathrm{Ba}$ & 0.00 & 0.00 & 0.00 & 0.00 & 0.00 & 0.00 & 0.00 & 0.00 \\
\hline K & 0.00 & 0.00 & 0.00 & 0.00 & 0.00 & 0.00 & 0.00 & 0.00 \\
\hline $\mathrm{Na}$ & 0.00 & 0.60 & 0.80 & 0.77 & 0.06 & 0.00 & 0.00 & 0.00 \\
\hline $\mathrm{Sr}$ & 0.15 & 0.05 & 0.04 & 0.04 & 0.07 & 0.09 & 0.10 & 0.15 \\
\hline $\mathrm{Ca}$ & 0.40 & 1.10 & 1.07 & 1.03 & 0.39 & 0.10 & 0.10 & 0.13 \\
\hline $\mathrm{Pb}$ & 0.00 & 0.00 & 0.00 & 0.00 & 0.78 & 0.73 & 0.60 & 0.55 \\
\hline $\mathrm{U}$ & 0.04 & 0.00 & 0.00 & 0.00 & 0.00 & 0.00 & 0.00 & 0.00 \\
\hline Th & 0.14 & 0.00 & 0.00 & 0.00 & 0.00 & 0.00 & 0.00 & 0.00 \\
\hline $\mathrm{Y}$ & 0.00 & 0.03 & 0.01 & 0.01 & 0.00 & 0.00 & 0.00 & 0.00 \\
\hline $\mathrm{La}$ & 0.01 & 0.00 & 0.01 & 0.01 & 0.00 & 0.07 & 0.09 & 0.08 \\
\hline $\mathrm{Ce}$ & 0.06 & 0.02 & 0.02 & 0.02 & 0.02 & 0.13 & 0.17 & 0.16 \\
\hline $\mathrm{Nd}$ & 0.01 & 0.00 & 0.00 & 0.00 & 0.00 & 0.01 & 0.02 & 0.01 \\
\hline $\mathrm{Sm}$ & 0.00 & 0.00 & 0.00 & 0.00 & 0.00 & 0.00 & 0.00 & 0.00 \\
\hline$\sum$ cat $(\mathrm{A})$ & 0.81 & 1.80 & 1.96 & 1.90 & 1.33 & 1.13 & 1.08 & 1.07 \\
\hline $\operatorname{Vac}(\mathrm{A})$ & 1.19 & 0.20 & 0.04 & 0.10 & 0.67 & 0.87 & 0.92 & 0.93 \\
\hline $\mathrm{Si}$ & 0.22 & 0.00 & 0.01 & 0.02 & 0.04 & 0.01 & 0.02 & 0.05 \\
\hline $\mathrm{Ti}$ & 0.42 & 0.25 & 0.22 & 0.23 & 0.19 & 0.22 & 0.20 & 0.13 \\
\hline $\mathrm{Fe}$ & 0.17 & 0.02 & 0.01 & 0.01 & 0.05 & 0.04 & 0.05 & 0.04 \\
\hline $\mathrm{Zr}$ & 0.00 & 0.00 & 0.01 & 0.01 & 0.00 & 0.00 & 0.00 & 0.00 \\
\hline $\mathrm{Nb}$ & 1.19 & 1.73 & 1.76 & 1.73 & 1.72 & 1.73 & 1.73 & 1.78 \\
\hline Ta & 0.00 & 0.00 & 0.00 & 0.00 & 0.00 & 0.00 & 0.00 & 0.00 \\
\hline$\Sigma$ cat $(\mathrm{B})$ & 2.00 & 2.00 & 2.00 & 2.00 & 2.00 & 2.00 & 2.00 & 2.00 \\
\hline $\mathrm{F}$ & 0.00 & 0.80 & 0.54 & 0.53 & 0.00 & 0.00 & 0.00 & 0.00 \\
\hline
\end{tabular}

\section{Discussion}

The distribution of titanium oxides in all studied rocks was constrained by networks of cracks. Thus, titanium oxides were deposited at the postmagmatic stage, after the rocks were deformed and brittle. Several mixed-aged generations of these constraining cracks were observed in titaniferous carbonatites. The earliest cracks were dampened by imposed processes (K-feldspar formation, 
apatitization, etc.), indicating the first portions of $\mathrm{TiO}_{2}$ to be deposited before the main stage of the metasomatic reconstruction.

The general order of mineral paragenesis in titaniferous carbonatites is as follows: (1) anatase, (2) Nb-poor brookite, (3) rutile, and (4) $\mathrm{Nb}$-rich brookite. This sequence is reduced up to the first two members in $\mathrm{TiO}_{2}$-carbonate veinlets from primary dolomite carbonatites in rimmings of $\mathrm{Ti}$ varieties. As mentioned, brookite-anatase glomers from $\mathrm{TiO}_{2}$-carbonate veinlets and brookite segregations of I type (associations of elongated crystals) from titaniferous carbonatites were definitely similar. Obviously, the appearance of dolomite carbonatites with $\mathrm{TiO}_{2}$-carbonate veinlets provides an idea about how "ordinary" carbonatites turned into titaniferous carbonatites at the earliest stages. Here, anatase must be more widespread, but the majority was paramorphically transformed into brookite after fluid processing. Simultaneously, the main amount of brookite from titaniferous carbonatites, which cemented earlier titanium oxides and other minerals, formed under the K-metasomatism. The difference in segregation forms and distribution scope of the "cementing" brookite produced a wide range of $\mathrm{TiO}_{2}$ morphotypes.

Judging by a number of admixtures, rutile was altered during the apatitization imposed on the K-metasomatism. Considering the structural features, this mineral paramorphically substituted brookite. As noted above, despite a mosaic distribution of elements (niobium, first of all), amoeboid isolations of $\mathrm{TiO}_{2}$ included individual monocrystals, where brookites of pre-(Nb-poor) and postrutile ( $\mathrm{Nb}$-rich) generations were intergrown. Recrystallization appears to have occurred when the late (Nb-rich) generation of brookite formed after rutile.

The stability field of rutile and the limiting P-T conditions for anatase-rutile and brookite-rutile conversions were reliably determined. However, the stability fields of anatase and brookite overlap each other ([40]; see their Figure 1). Therefore, during the synthesis of titanium dioxide, obtaining a mixture of two metastable low-temperature phases (brookite and anatase) is common, whereas serious efforts are required to selectively obtain anatase or brookite (e.g., [41,42] and many others). The leading role in the formation of a particular polymorph in chemical synthesis (and, most likely, in natural systems) acquires the characteristics of the fluid, including chemical composition, Eh, pH, etc. In this case, a substitution of one metastable phase by another, especially considering the paramorphic transitions, resulted in a dynamic change in the composition of the fluid in the course of mineral formation. However, even a short-term increase in temperature should have led to an increase in the stability of the high-temperature modification and, therefore, to irreversible partial or complete replacement of metastable brookite and anatase with a stable rutile phase [43]. As such, the sequence and completeness of conversion into rutile largely depended on the composition of the precursor (brookite or anatase). For instance, niobium was found to inhibit the brookite-rutile reaction [44], and Hanaor and Sorrell [45] showed that the anatase-rutile transition is hampered not only by niobium, but also by many other elements.

Thus, the change in $\mathrm{TiO}_{2}$ politypes is an evolutionary sequence in which members are closely related to the changing conditions of associated metasomatic reconstructions in rocks. In the current sequence, the niobium content reasonably increased, as detected in other similar objects as well [23]. Formed at the peak of niobium stocks in titaniferous carbonatites are (1) the above mentioned post-rutile $\mathrm{Nb}$-rich generation of brookite in various morphotypes of $\mathrm{TiO}_{2}$-segregations, and (2) idiomorphic brookite (V type) and pyrochlore in association with dolomite from by-selvedge areas of cutting carbonatite veinlets. At this stage, niobium rims occur in dolomite carbonatites from edging of titaniferous varieties. These rims impregnated anatase and brookite that formed earlier. Areas with the pyrochlore mineralization occurred at that time.

As stated above, many studies of carbonatite objects consider pyrochlore a sensitive indicator of processes imposed on a rock. Observing, though, the same changes in the pyrochlore chemical activity in different complexes, we tend to disagree on the nature of these phenomena. First of all, these phenomena concern the dividing of the late metasomatic and hypergene stages of the pyrochlore 
genesis. Based on an analysis of the literary data, the evolution of the pyrochlore composition could follow this general order:

(1) Fluorcalciopyrochlore with the fully filled $A$-sites is the main variety in magmatic calcite $[29,46-48]$ and dolomite [31,49] carbonatites. Th-U [50] varieties are less frequent, also with a minor amount of vacancies in $A$-site and dominant $\mathrm{F}$ in $Y$-site.

(2) Fluorcalciopyrochlore is naturally substituted by varieties, whereas in the $A$-site (1) Ca and $\mathrm{Na}$ contents decrease, (2) cations become minor up to xenopyrochlores ( $A$-vacancy $>$ 1 a.p.f.u), and (3) $\mathrm{Ba}, \mathrm{Sr}, \mathrm{REE}, \mathrm{Th}, \mathrm{U}, \mathrm{Pb}$, and $\mathrm{H}_{2} \mathrm{O}$ become the dominant cations. In the $B$-site, a decreasing trend in $\mathrm{Nb}$ content isomorphically substituted by $\mathrm{Ti}$ and Fe occurs. $Y$-site is characterized by $\mathrm{F}$ decreasing until it disappears, and OH-groups occur in this position. Different authors have linked this chemical specific feature of pyrochlores with magmatic [51], hydrothemal $[27,28,31,49,52-54]$, or supergene $[55,56]$ processes. The "hydrothermal" point of view prevails.

(3) In pyrochlores that are most reasonably referred to supergenous [17,49,56,57], the same chemical features are the most manifested. $\mathrm{Ba}, \mathrm{Sr}, \mathrm{REE}, \mathrm{Th}, \mathrm{U}, \mathrm{Pb}, \mathrm{H}_{2} \mathrm{O}$, and rarely $\mathrm{K}$ remain the dominant cations in the $A$-site, but in general, the occupancy rate of this position drops to the lowest level, down to zero. Ca and/or Na tend to disappear. No fluorine-varieties are detected among supergenous pyrochlore. They differ from "hydrothermal" pyrochlores with the B-site completely filled with niobium. With a vacant $A$-site, it makes supergenous pyrochlores become the richest in niobium: $75 \mathrm{wt} \%$ vs. $50 \mathrm{wt} \%$ in other varieties.

U-Th and Ca-F-varieties represent early generations of the Petyayan-Vara pyrochlore and are commonly interpreted as magmatism products. However, the structural position of the pyrochlore localized in mineralized veinlets supports its fluid nature, which is also indicated by some of its chemical features. Thus, the earliest U-Th pyrochlore lacked $A$-site filling and fluorine. According to their characteristics, they are similar to pyrochlores from ankerite carbonatites of some Indian complexes [58-60]. The studied fluorcalciopyrochlore is compositionally identical to magmatic carbonatites. However, we note that fluorcalciopyrochlore from the well-known Nb-REE Bayan Obo deposit was originally described as a product of REE-, F-rich postmagmatic hydrothermal solutions impact on Ca-Mg-carbonatites [61]. Moreover, in exocontact rocks (fenites) of late carbonatites a priori fluid pyrochlore mineralization is also usually represented by fluorcalciopyrochlore [56,62]. We suggest both U-Th, and Ca-F-varieties of pyrochlore formed when apatite occurred in titaniferous carbonatites, which is indicated by the similar chemical features of both minerals (e.g., increased contents of Th, Y, Sr, etc.).

The pseudomorph substitution of $\mathrm{Ca}$-F-pyrochlore by a rare fluorine-free $\mathrm{Pb}$-variety is a specific feature of the Petyayan-Vara carbonatites. Commonly, the transition passes through a number of intermediate areas of Ba-, Sr-, and REE-pyrochlores [28,63]. The pyrochlores reflect the general pattern of imposed metasomatic processes in such areas, including the Petyayan-Vara ore field rocks. Direct transitions to $\mathrm{Pb}$-pyrochlore are only present in fenite around the Chilwa Island Carbonatite, Malawi [64]. An association of Pb-pyroclore and later monazite is typical in both cases, as well as the mentioned fenites. We presume the absence of transition areas to be a result of specific geological features of the Petyayan-Vara titaniferous carbonatites. These rocks are supposed to have almost no imposed Ba-, Sr-, or REE-metasomatic processes due to their dense fine-grained structure obtained during recrystallization. We think that the peculiar evolution of pyrochlore in titaniferous carbonatites of the Petyayan-Vara confirms the conception that emerged in our minds during this field study that was strengthened while analyzing the geochemistry of the rocks. Apparently, within the Petyayan-Vara carbonatite field (1) there are products of all major processes typical of late carbonatites and (2) these products are often spatially isolated. Therefore, the Petyaya-Vara rocks provide a unique ground for the differentiated study of the late carbonatite genesis. 
Despite this, the formation mechanism of titaniferous carbonatites is still not completely clear. Large-scale metasomatic transfer of titanium is assumed to be hardly possible [65]. Therefore, the probable source of titanium and niobium are the enclosing aluminosilicate rocks. Remobilization of components from the latter by carbonatite-hosted fluids can also explain other specific geochemical features of titaniferous carbonatites. For example, their enrichment in such atypical elements for carbonatitic melts as $\mathrm{Al}$ and Si. However, we cannot unequivocally deny the probability of HFSE introduction by fluid from a remote source. As mentioned before, the rare-earth carbonatites of the Petyayan-Vara are predominantly ancylitic. This is rather unusual, since in most such complexes, the main REE-carbonate is bastnaesite [66]. However, this is not unique. The second largest deposit of rare earths in the U.S. (Bear Lodge alkaline complex, Wyoming) is also ancylitic [67]. Based on the available information on the geology of the Bear Lodge REE carbonatites [13], the similarity of the complexes is both mineralogical and geochemical. Within the Bear Lodge complex, zones with HFSE-mineralization occur but they are larger than those at the Petyayan-Vara. The rocks of one of such zones, known as the Cole HFSE(+HREE) Occurrence, contains up to $44.9 \% \mathrm{TiO}_{2}, 3.1 \% \mathrm{Nb}_{2} \mathrm{O}_{5}$, $6.5 \% \mathrm{Y}_{2} \mathrm{O}_{3}, 0.8 \% \mathrm{Dy}_{2} \mathrm{O}_{3}, 2.6 \% \mathrm{ThO}_{2}, 6.0 \% \mathrm{P}_{2} \mathrm{O}_{5}$, and 3.7\% F. They are composed of K-feldspar $(30-40 \%)$ and $\mathrm{Nb}$-rich anatase (30-50\%) [68]. In contrast to the Petyayan-Vara, these rocks are located outside the massif (about two km from the main carbonatite intrusions) among sedimentary rocks poor in the listed components. Such geological conditions allowed Andersen et al. [ibid.] to conclude that “... HFSEs and HREEs are transported in highly fractionated F-rich fluids of high-ionic strength that originated from carbonatite intrusions or associated carbohydrothermal residua". Considering the similarity between the massifs in general and the HFSE-rich rocks in particular, we admit the possibility of Ti-Nb fluid influx from deeper levels of the Petyayan-Vara complex.

Regardless of the source, titanium and niobium apparently migrated together. Complexes with halogens ([69] and its references) and, to a lesser extent, $\mathrm{CO}_{3}{ }^{2-}$ and $\mathrm{PO}_{4}{ }^{3-}$ ligands [70], played a decisive role in the transfer of these elements. In our case, the main transfer agent was fluorine. This is indicated by the presence of fluorapatite, fluorcalciopyrochlore and F-rich phlogopite in the rocks. The intergrowths of Ti-oxides with sulphides may indicate the involvement of S-bearing ligands. As with the formation of HFSE-rocks in the Bear Lodge, the deposition of Ti in the Petyayan-Vara's titaniferous carbonatites was probably facilitated by a decrease in temperature and fluid-carbonatite interactions. However, unlike most similar massifs, fluorite was not formed. This preserved niobium in the fluid phase. Moreover, according to recent studies [71], when the high HF content in solution is high, a decrease in temperature could lead to an increase in the solubility of $\mathrm{Nb}$ as niobium hydroxyl-fluoride species and its accumulation in the residual fluid. Further migration of this residual fluid to adjacent dolomite carbonatites formed the chain-like pyrochlore mineralization and $\mathrm{Nb}$-rich rims in anatase and brookite from $\mathrm{TiO}_{2}$-carbonate veinlets. The apatitization process could trigger niobium deposition (the formation of the late $\mathrm{Nb}$-rich generation of brookite and fluorcalciopyrochlore) in the titaniferous carbonatites. Apparently, this process caused the deposition of fluorine from the fluid. Simultaneously, temperature increased, which caused a paramorphic conversion of brookite into rutile.

\section{Conclusions and Perspectives}

The peak of niobium stocks in the Vuoriyarvi massif was during the magmatic stage of its genesis, as found in other carbonatite massifs around the world. It produced the Neske-Vara pyrochlore deposit. However, titanium concentrated under the formation of late (titaniferous) carbonatites before the Ba-Sr-REE metasomatism.

Fluids played the main role in the genesis of the studied rocks. Judging by dynamically swapping titanium oxides and widespread paramorphic transitions, this pre-REE stage was associated with actively changing physical and chemical parameters.

Niobium accumulated in specific residual fluids, low in titanium at that time. The impact of this residual fluid led to the formation of pyrochlore, late generation of $\mathrm{Nb}$-rich brookite in titaniferous carbonatites and $\mathrm{Nb}$-rich rims impregnating early generations of anatase and brookite 
from $\mathrm{TiO}_{2}$-carbonate veinlets. This created the second peak in niobium stocks, but not as large-scale, as the one occurred during the magmatism.

Along with $\mathrm{Mg}$ and $\mathrm{Fe}$, titanium and niobium were the most mobile components in the considered metasomatic processes. Even the inflow of mobile elements, such as alkali, was a catch-up, as indicated by pyrochlore resorbed by phlogopite.

Thus, we obtained a general view at the chemical separation of HFSE from other elements and their isolation. The studied processes occurred at a specific stage of the matter differentiation, which preceded the formation of rare-earth carbonatites and is likely to be tightly interwoven. Since almost no publications on late carbonatites (including REE) goes without mentioning $\mathrm{Nb}$-rich titanium oxides, we consider it important to address the following issues that are both practically, and theoretically topical: the source of $\mathrm{Ti}-\mathrm{Nb}$ fluids and the mechanism of their formation. Unfortunately, the data required to answer these questions are still lacking. We expect that the answer will be determined through studies of fluid inclusions, as well as radiogenic and stable isotope systematics.

Author Contributions: E.K. conceived and designed the experiments; E.K., E.F. and M.S. conducted field research; E.K. studied petrography and mineralogy of rocks; E.F. described the mineralogy of $\mathrm{TiO}_{2}$ phases; M.S. investigated the pyrochlore mineralization; V.S. made electron back scattered diffraction (EBSD) measurements, backscattered electrons (BSE) images and analyzed the chemical composition of the minerals. All the authors participated in the writing of the paper.

Funding: This research was funded by the Russian Foundation for Basic Research grant number 16-35-00132].

Acknowledgments: This work was carried out in the Geological Institute KSC RAS under the state order No. 0231-2015-0009. The authors express their sincere appreciation to T.A. Miroshnichenko for help with translation. We also thank A.V. Chernyavskiy (GI KSC RAS) for his help in the field works, as well as V.N. Bocharov (RC "Geomodel" SPbSU) and A.V. Bazai (GI KSC RAS) for their assistance in studying the structure and composition of the minerals. The authors express their sincere gratitude to two anonymous reviewers.

Conflicts of Interest: The authors declare no conflict of interest.

\section{References}

1. Le Maitre, R.W.; Streckeisen, A.; Zanettin, B.; Le Bas, M.J.; Bonin, B.; Bateman, P.; Bellieni, G.; Dudek, A.; Efremova, S.; Keller, J.; et al. Igneous Rocks: A Classification and Glossary of Terms. Recommendations of the International Union of Geological Sciences Subcommission on the Systematics of Igneous Rocks, 2nd ed.; Le Maitre, R.W., Ed.; Cambridge University Press: Cambridge, UK, 2002; ISBN 9780521619486.

2. Woolley, A.R.; Kempe, D.R.C. Carbonatites: Nomenclature, average chemical compositions, and element distribution. In Carbonatites: Genesis and Evolution; Bell, K., Ed.; Unwin Hyman: London, UK, 1989; pp. 1-14.

3. Jones, A.P.; Genge, M.; Carmody, L. Carbonate Melts and Carbonatites. Rev. Mineral. Geochem. 2013, 75, 289-322. [CrossRef]

4. Le Bas, M.J. Ferrocarbonatites: Geochemistry and magma-fluid state. Mem. Geol. Soc. India 1999, 43, 785-802.

5. Weng, Z.; Jowitt, S.M.; Mudd, G.M.; Haque, N. A Detailed Assessment of Global Rare Earth Element Resources: Opportunities and Challenges. Econ. Geol. 2015, 110, 1925-1952. [CrossRef]

6. Goodenough, K.M.; Wall, F.; Merriman, D. The Rare Earth Elements: Demand, Global Resources, and Challenges for Resourcing Future Generations. Nat. Resour. Res. 2018, 27, 201-216. [CrossRef]

7. Doroshkevich, A.G.; Viladkar, S.G.; Ripp, G.S.; Burtseva, M.V. Hydrothermal REE mineralization in the Amba Dongar carbonatite complex, Gujarat, India. Can. Mineral. 2009, 47, 1105-1116. [CrossRef]

8. Trofanenko, J.; Williams-Jones, A.E.; Simandl, G.J.; Migdisov, A.A. The Nature and Origin of the REE Mineralization in the Wicheeda Carbonatite, British Columbia, Canada. Econ. Geol. 2016, 111, 199-223. [CrossRef]

9. Ngwenya, B.T. Hydrothermal rare earth mineralisation in carbonatites of the Tundulu complex, Malawi: Processes at the fluid/rock interface. Geochim. Cosmochim. Acta 1994, 58, 2061-2072. [CrossRef]

10. Broom-Fendley, S.; Styles, M.T.; Appleton, J.D.; Gunn, G.; Wall, F. Evidence for dissolution-reprecipitation of apatite and preferential LREE mobility in carbonatite-derived late-stage hydrothermal processes. Am. Mineral. 2016, 101, 596-611. [CrossRef] 
11. Cooper, A.F.; Collins, A.K.; Palin, J.M.; Spratt, J. Mineralogical evolution and REE mobility during crystallisation of ancylite-bearing ferrocarbonatite, Haast River, New Zealand. Lithos 2015, 216-217, 324-337. [CrossRef]

12. Duraiswami, R.; Shaikh, T. Fluid-rock interaction in the Kangankunde Carbonatite Complex, Malawi: SEM based evidence for late stage pervasive hydrothermal mineralisation. Open Geosci. 2014, 6. [CrossRef]

13. Moore, M.; Chakhmouradian, A.R.; Mariano, A.N.; Sidhu, R. Evolution of rare-earth mineralization in the Bear Lodge carbonatite, Wyoming: Mineralogical and isotopic evidence. Ore Geol. Rev. 2015, 64, 499-521. [CrossRef]

14. Prokopyev, I.R.; Borisenko, A.S.; Borovikov, A.A.; Pavlova, G.G. Origin of REE-rich ferrocarbonatites in southern Siberia (Russia): Implications based on melt and fluid inclusions. Mineral. Petrol. 2016, 110, 845-859. [CrossRef]

15. Nadeau, O.; Cayer, A.; Pelletier, M.; Stevenson, R.; Jébrak, M. The Paleoproterozoic Montviel carbonatite-hosted REE-Nb deposit, Abitibi, Canada: Geology, mineralogy, geochemistry and genesis. Ore Geol. Rev. 2015, 67, 314-335. [CrossRef]

16. Zaitsev, A.N.; Wall, F.; Bas, M.J. Le REE-Sr-Ba minerals from the Khibina carbonatites, Kola Peninsula, Russia: Their mineralogy, paragenesis and evolution. Mineral. Mag. 1998, 62, 225-250. [CrossRef]

17. Mitchell, R.H. Primary and secondary niobium mineral deposits associated with carbonatites. Ore Geol. Rev. 2015, 64, 626-641. [CrossRef]

18. Mitchell, R.H. Carbonatites and Carbonatites and Carbonatites. Can. Mineral. 2005, 43, 2049-2068. [CrossRef]

19. Chakhmouradian, A.R. High-field-strength elements in carbonatitic rocks: Geochemistry, crystal chemistry and significance for constraining the sources of carbonatites. Chem. Geol. 2006, 235, 138-160. [CrossRef]

20. Fryklund, V.C.; Harner, R.S.; Kaiser, E.P. Niobium (Columbium) and titanium at Magnet Cove and Potash Sulphur Springs, Arkansas. Geol. Surv. Bull. 1954, 1015B, 23-56.

21. Flohr, M.J.K. Titanium, vanadium, and niobium mineralization and alkali metasomatism from the Magnet Cove complex, Arkansas. Econ. Geol. 1994, 89, 105-130. [CrossRef]

22. Verwoerd, W.J.; Viljoen, E.A.; Chevallier, L. Rare metal mineralization at the Salpeterkop carbonatite complex, Western Cape Province, South Africa. J. Afr. Earth Sci. 1995, 21, 171-186. [CrossRef]

23. Werner, M.; Cook, N.J. Nb-rich brookite from Gross Brukkaros, Namibia: Substitution mechanisms and $\mathrm{Fe}^{2+} / \mathrm{Fe}^{3+}$ ratios. Mineral. Mag. 2001, 65, 437-440. [CrossRef]

24. Kapustin, I.L. Mineralogy of Carbonatites; Amerind Publishing Company Pvt. Ltd.: New Dehli, India, 1980.

25. Giovannini, A.L.; Bastos Neto, A.C.; Porto, C.G.; Pereira, V.P.; Takehara, L.; Barbanson, L.; Bastos, P.H.S. Mineralogy and geochemistry of laterites from the Morro dos Seis Lagos $\mathrm{Nb}$ (Ti, REE) deposit (Amazonas, Brazil). Ore Geol. Rev. 2017, 88, 461-480. [CrossRef]

26. Howard, J.M. Brookite, Rutile Paramorphs after Brookite, and Rutile Twins from Magnet Cove, Arkansas. Rocks Miner. 1999, 74, 92-102. [CrossRef]

27. Khromova, E.A.; Doroshkevich, A.G.; Sharygin, V.V.; Izbrodin, L.A. Compositional Evolution of Pyrochlore-Group Minerals in Carbonatites of the Belaya Zima Pluton, Eastern Sayan. Geol. Ore Depos. 2017, 59, 752-764. [CrossRef]

28. Melgarejo, J.C.; Costanzo, A.; Bambi, A.C.J.M.; Gonçalves, A.O.; Neto, A.B. Subsolidus processes as a key factor on the distribution of $\mathrm{Nb}$ species in plutonic carbonatites: The Tchivira case, Angola. Lithos 2012, 152, 187-201. [CrossRef]

29. Torro, L.; Villanova, C.; Castillo, M.; Campeny, M.; Gonçalves, A.O.; Melgarejo, J.C. Niobium and rare earth minerals from the Virulundo carbonatite, Namibe, Angola. Mineral. Mag. 2012, 76, 393-409. [CrossRef]

30. Kapustin, Y.L. Mineralogy of the Weathering Crust of Carbonatites; Nedra: Moscow, Russia, 1973. (In Russian)

31. Tremblay, J.; Bédard, L.P.; Matton, G. Columbitization of fluorcalciopyrochlore by hydrothermalism at the Saint-Honoré alkaline complex, Québec (Canada): New insights on halite in carbonatites. Ore Geol. Rev. 2017, 91, 695-707. [CrossRef]

32. Downes, H.; Balaganskaya, E.; Beard, A.; Liferovich, R.; Demaiffe, D. Petrogenetic processes in the ultramafic, alkaline and carbonatitic magmatism in the Kola Alkaline Province: A review. Lithos 2005, 85, 48-75. [CrossRef]

33. Afanasyev, B.V. Mineral Resources of the Alkaline-Ultramafic Massifs of the Kola Peninsula; Roza Vetrov: St. Petersburg, Russia, 2011. (In Russian) 
34. Gittins, J.; Harmer, R.E. What is ferrocarbonatite? A revised classification. J. Afr. Earth Sci. 1997, 25, $159-168$. [CrossRef]

35. Tompsett, G.A.; Bowmaker, G.A.; Cooney, R.P.; Metson, J.B.; Rodgers, K.A.; Seakins, J.M. The Raman spectrum of brookite, $\mathrm{TiO}_{2}(\mathrm{Pbca}, \mathrm{Z}=8$ ). J. Raman Spectrosc. 1995, 26, 57-62. [CrossRef]

36. Kravchenko-Berezhnoy, R.A.; Medvedeva, E.M.; Pakhomovsky, Y.A.; Polezhaeva, L.I.; Rezhenova, S.A. Combined usage of microprobe MS-46 and computer 'Nairi-2'. In Instrumental Methods of Mineral Studies and Usage of Electronic Computing Devices; Kravchenko-Berezhnoy, R.A., Ed.; Kola Branch USSR Academy of Sciences: Apatity, Russia, 1976; pp. 46-69.

37. Atencio, D.; Gieré, R.; Andrade, M.B.; Christy, A.G.; Kartashov, P.M. The pyrochlore supergroup of minerals: Nomenclature. Can. Mineral. 2010, 48, 673-678. [CrossRef]

38. Meinhold, G. Rutile and its applications in earth sciences. Earth-Sci. Rev. 2010, 102, 1-28. [CrossRef]

39. Bonazzi, P.; Bindi, L.; Zoppi, M.; Capitani, G.C.; Olmi, F. Single-crystal diffraction and transmission electron microscopy studies of 'silicified' pyrochlore from Narssarssuk, Julianehaab district, Greenland. Am. Mineral. 2006, 91, 794-801. [CrossRef]

40. Plavsa, D.; Reddy, S.M.; Agangi, A.; Clark, C.; Kylander-Clark, A.; Tiddy, C.J. Microstructural, trace element and geochronological characterization of $\mathrm{TiO}_{2}$ polymorphs and implications for mineral exploration. Chem. Geol. 2018, 476, 130-149. [CrossRef]

41. Jiao, Y.; Chen, F.; Zhang, L.; Zhou, E.; Zhang, J. Hydrothermal synthesis of anatase and brookite nanotubes with superior photocatalytic and Li+insertion/extraction performances. Catal. Commun. 2014, 47, 32-35. [CrossRef]

42. Leal, J.H.; Cantu, Y.; Gonzalez, D.F.; Parsons, J.G. Brookite and anatase nanomaterial polymorphs of $\mathrm{TiO}_{2}$ synthesized from $\mathrm{TiCl}_{3}$. Inorg. Chem. Commun. 2017, 84, 28-32. [CrossRef]

43. Dachille, F.; Simons, P.Y.; Roy, R. Pressure-Temperatue studies of anatase, brookite, rutile and $\mathrm{TiO}_{2}-\mathrm{II}$. Am. Mineral. 1968, 53, 1929-1939.

44. Huberty, J.; $\mathrm{Xu}, \mathrm{H}$. Kinetics study on phase transformation from titania polymorph brookite to rutile. J. Solid State Chem. 2008, 181, 508-514. [CrossRef]

45. Hanaor, D.A.H.; Sorrell, C.C. Review of the anatase to rutile phase transformation. J. Mater. Sci. 2011, 46, 855-874. [CrossRef]

46. Boniface, N. Crystal chemistry of pyrochlore from the Mesozoic Panda Hill carbonatite deposit, western Tanzania. J. Afr. Earth Sci. 2017, 126, 33-44. [CrossRef]

47. Zurevinski, S.E.; Mitchell, R.H. Extreme compositional variation of pyrochlore-group minerals at the Oka carbonatite complex, Quebec: Evidence of magma mixing? Can. Mineral. 2004, 42, 1159-1168. [CrossRef]

48. Sharygin, V.V.; Doroshkevich, A.G. Mineralogy of secondary olivine-hosted inclusions in calcite carbonatites of the Belaya Zima alkaline complex, Eastern Sayan, Russia: Evidence for late-magmatic Na-Ca-rich carbonate composition. J. Geol. Soc. India 2017, 90, 524-530. [CrossRef]

49. Chakhmouradian, A.R.; Mitchell, R.H. Lueshite, pyrochlore and monazite-(Ce) from apatite-dolomite carbonatite, Lesnaya Varaka complex, Kola Peninsula, Russia. Mineral. Mag. 1998, 62, 769-782. [CrossRef]

50. Kogarko, L.N.; Sorokhtina, N.V.; Kononkova, N.N.; Klimovich, I.V. Uranium and thorium in carbonatitic minerals from the Guli massif, Polar Siberia. Geochem. Int. 2013, 51,767-776. [CrossRef]

51. Bambi, A.C.J.M.; Costanzo, A.; Gonçalves, A.O.; Melgarejo, J.C. Tracing the chemical evolution of primary pyrochlore from plutonic to volcanic carbonatites: The role of fluorine. Mineral. Mag. 2012, 76, 377-392. [CrossRef]

52. Lumpkin, G.R.; Ewing, R.C. Geochemical alteration of pyrochlore group minerals; pyrochlore subgroup. Am. Mineral. 1995, 80, 732-743. [CrossRef]

53. Zheng, L.; Gu, X.; Zhang, Y. Pyrochlore Chemistry from the Bonga Carbonatite-type Nb Deposit, Huila Province, Angola: Implications for Magmatic-Hydrothermal Processes of Carbonatite. Acta Geol. Sin. Engl. Ed. 2014, 88, 487-488. [CrossRef]

54. Chebotarev, D.A.; Doroshkevich, A.G.; Klemd, R.; Karmanov, N.S. Evolution of Nb-mineralization in the Chuktukon carbonatite massif, Chadobets upland (Krasnoyarsk Territory, Russia). Period. Mineral. 2017, 86, 99-118. [CrossRef]

55. Jo, A.; Bambi, C.M.; Costanzo, A.; Melgarejo, J.C.; Gon, A.O.; Alfonso, P.; Neto, A.B.; Manuel, J. Evolution of Pyrochlore in Carbonatites: The Angola Case. Rev. Soc. Esp. Mineral. 2008, 9, 43-44. 
56. Wall, F.; Williams, C.T.; Woolley, A.R.; Nasraoui, M. Pyrochlore from Weathered Carbonatite at Lueshe, Zaire. Mineral. Mag. 1996, 60, 731-750. [CrossRef]

57. Williams, C.; Wall, F.; Woolley, A.; Phillipo, S. Compositional variation in pyrochlore from the Bingo carbonatite, Zaïre. J. Afr. Earth Sci. 1997, 25, 137-145. [CrossRef]

58. Viladkar, S.G.; Ghose, I. U-rich pyrochlore in carbonatite of Newania, Rajasthan. Neues Jahrb. Mineral. Monatshefte 2002, 2002, 97-106. [CrossRef]

59. Viladkar, S.G.; Bismayer, U.; Zietlow, P. Metamict U-rich pyrochlore of Newania carbonatite, Udaipur, Rajasthan. J. Geol. Soc. India 2017, 89, 133-138. [CrossRef]

60. Viladkar, S.G.; Bismayer, U. U-rich pyrochlore from sevathur carbonatites, Tamil Nadu. J. Geol. Soc. India 2014, 83, 175-182. [CrossRef]

61. Guowu, L.; Guangming, Y.; Fude, L.; Ming, X.; Xiangkun, G.; Baoming, P.; de Fourestier, J. Fluorcalciopyrochlore, A New Mineral Species From Bayan Obo, Inner Mongolia, P.R. China. Can. Mineral. 2016, 54, 1285-1291. [CrossRef]

62. Chakhmouradian, A.R.; Reguir, E.P.; Kressall, R.D.; Crozier, J.; Pisiak, L.K.; Sidhu, R.; Yang, P. Carbonatite-hosted niobium deposit at Aley, northern British Columbia (Canada): Mineralogy, geochemistry and petrogenesis. Ore Geol. Rev. 2015, 64, 642-666. [CrossRef]

63. Lazareva, E.V.; Zhmodik, S.M.; Dobretsov, N.L.; Tolstov, A.V.; Shcherbov, B.L.; Karmanov, N.S.; Gerasimov, E.Y.; Bryanskaya, A.V. Main minerals of abnormally high-grade ores of the Tomtor deposit (Arctic Siberia). Russ. Geol. Geophys. 2015, 56, 844-873. [CrossRef]

64. Dowman, E.; Wall, F.; Treloar, P.J.; Rankin, A.H. Rare-earth mobility as a result of multiple phases of fluid activity in fenite around the Chilwa Island Carbonatite, Malawi. Mineral. Mag. 2017, 81, 1367-1395. [CrossRef]

65. Van Baalen, M.R. Titanium mobility in metamorphic systems: A review. Chem. Geol. 1993, 110, $233-249$. [CrossRef]

66. Voncken, J.H.L. The Rare Earth Elements; SpringerBriefs in Earth Sciences; Springer International Publishing: Cham, Switzerland, 2016; ISBN 978-3-319-26807-1.

67. Mariano, A.N.; Mariano, A. Rare Earth Mining and Exploration in North America. Elements 2012, 8, 369-376. [CrossRef]

68. Andersen, A.K.; Clark, J.G.; Larson, P.B.; Neill, O.K. Mineral chemistry and petrogenesis of a HFSE(+HREE) occurrence, peripheral to carbonatites of the Bear Lodge alkaline complex, Wyoming. Am. Mineral. 2016, 101, 1604-1623. [CrossRef]

69. Hammerli, J.; Rubenach, M. The Role of Halogens during Regional and Contact Metamorphism. In The Role of Halogens in Terrestrial and Extraterrestrial Geochemical Processes; Harlov, D.E., Aranovich, L., Eds.; Springer Geochemistry; Springer International Publishing: Cham, Switzerland, 2018; pp. 649-712. ISBN 978-3-319-61665-0.

70. Gieré, R. Hydrothermal mobility of Ti, Zr and REE: Examples from the Bergell and Adamello contact aureoles (Italy). Terra Nova 1990, 2, 60-67. [CrossRef]

71. Timofeev, A.; Migdisov, A.A.; Williams-Jones, A.E. An experimental study of the solubility and speciation of niobium in fluoride-bearing aqueous solutions at elevated temperature. Geochim. Cosmochim. Acta 2015, 158, 103-111. [CrossRef]

(C) 2018 by the authors. Licensee MDPI, Basel, Switzerland. This article is an open access article distributed under the terms and conditions of the Creative Commons Attribution (CC BY) license (http://creativecommons.org/licenses/by/4.0/). 